\title{
Valgene til Rigsrådets folketing og landsting i krigens skygge $i$ 1864
}

\author{
Af Anders Hauge
}

Dagen før krigsudbruddet i 1864 mellem Danmark og de tyske stormagter blev der udskrevet valg til Rigsrådets folketing og landsting. Da valgene den 31. januar 1864 blev udskrevet, var de formentlig tænkt som et redskab til at forhindre krigen ved at få Rigsrådet sammenkaldt snarest og om muligt få ophævet krigens formelle årsag: Grundloven af 1863. Nu blev det krigen og okkupationen, der kom til at præge valgene. Visse steder opstod forsinkelser. Nogle steder var det umuligt at gennemføre valget. Andre steder igen måtte man gribe til bemærkelsesværdige ordninger for at få valgene gennemført, som det var tilfældet i de slesvigske landstingsvalgkredse. Valgene skulle gennemføres - om muligt.

Næppe var valget til Rigsrådet udskrevet, før krigen brød ud. Valgene til Rigsrådets folketing og landsting blev udskrevet den 31. januar 1864, og dagen efter overskred tropper fra de tyske stormagter Preussen og Østrig Ejderen og påbegyndte dermed besættelsen af hertugdømmet Slesvig. Valgene til Rigsrådets folketing var blevet fastsat til at skulle finde sted den 5. marts og valgene til Rigsrådets landsting den 29. marts. ${ }^{1}$

Det kan ikke undre, at krigsbegivenhederne nu kom til at sætte sig spor i afviklingen af valget til Rigsrådet. Spørgsmålet er, hvordan krigen kom til at sætte sit præg på valgets forberedelse, gennemførelse og resultat. Dette er emnet i denne fremstilling. I fokus er forholdene i Jylland i almindelighed og i Slesvig i særdeleshed. Det er derfor, der i særlig grad bringes slesvigsk personnavnestof.

I oversigtslitteraturen nævnes selve valget til Rigsrådet i 1864 kun flygtigt, hvis det overhovedet nævnes. Det afholdte valg eksisterer som en stiltiende forudsætning, når Rigsrådet nævnes enten i forbindelse med dets indkaldelse i juni eller i forbindelse med fredsslutningen. Nævnes det, er det i forbindelse med den højspændte politiske situation i januar måned. ${ }^{2}$ Indtrykket af, at andre begivenheder i 1864 
har overskygget valget, bekræftes af, at der synes at mangle selvstændig litteratur på området. ${ }^{3}$ Man kan dog være heldig at finde valget omtalt i andre sammenhænge af for eksempel biografisk art. ${ }^{4}$

Synsviklen er administrationshistorisk, idet hovedgrundlaget for fremstillingen er de i Finansministeriet og i Ministeriet for Hertugdømmet Slesvig beroende pakker om valget til Rigsrådet i 1864. Sagerne er $\mathrm{i}$ begge ministerier anbragt $\mathrm{i}$ særskilte grupper. Disse er $\mathrm{i}$ anvendelsen suppleret med forestillinger og journaler. Arkivalierne befinder sig i Rigsarkivet. Desuden er der gjort brug af Rigsrådets arkiv, der befinder sig i Folketingets Bibliotek på Christiansborg. ${ }^{5}$ Arkivalierne er gennemgået med henblik på at afdække nedslag af krigen i dem før, under og efter afviklingen af valget.

Der skal knyttes en særlig bemærkning til arkivet for Ministeriet for Hertugdømmet Slesvig. En del af pakken består af arkivalier, der ikke synes dannet i ministeriet, men af Den Interimistiske Overøvrighed for Vesterhavsøerne. Den var en af Ministeriet for Hertugdømmet Slesvig oprettet midlertidig amtmandsfunktion, der skulle fungere, så længe det slesvigske fastland var besat. $^{6}$

Ved at anlægge den nævnte administrationshistoriske vinkel er der samtidig sket en afgrænsning. De enkelte valgte kandidaters eventuelle politiske tilhørsforhold er ikke en del af fremstillingen. Samtidig er det klart, at fremstillingen gennem de anvendte kilder nødvendigvis må bygge på den officielle holdning, som jo - om end på en anden måde - er politisk.

Fremstillingen åbnes nedenfor ved at fremdrage en indberetning til Finansministeriet, der berører både valget og krigen samt det administrative. Indberetningen stammer fra biskoppen for Als-Ærø bispedømme, Jørgen Hansen. Han var valgbestyrelsesformand i 14. landstingsvalgkreds og forklarer i sin indberetning, hvorfor valget måtte udskydes fra den 29. marts til en senere dato, og hvorfor der i skrivende stund endnu ikke kunne berammes nogen ny valgdato. Valgbestyrelsen havde nemlig først meget sent modtaget det tilstrækkelige antal stemmesedler til udsendelse, og desuden krævede det tid for folk, hvoraf flertallet var bønder, ${ }^{7}$ til at sætte sig ind i tingene og få lejlighed til at samles, og han fortsætter: »Dette er på landet altid forbundet med vanskeligheder, men frem for alt på Als i denne tid, da ikke blot interessen for alt andet sløres ved ideligt at høre kanonerne, men også hestene den halve tid er i krigskørsel, og der den øvrige 
tid er meget at varetage med indkvartering osv." Når de udfyldte stemmesedler var kommet tilbage, skulle der nok blive afholdt optælling. At fastsætte en dato allerede nu lod sig ikke gøre, »dels fordi sørejsen fra Ærø ofte gør flere dages samkvem umuligt, og dels fordi belejringstilstanden som krigsforholdet i det hele gør det umuligt forud at disponere over nogen bestemt dag «. Han sluttede indberetningen med følgende lakoniske sætning: »At forholdet forandres, hvis øen skulle blive okkuperet af fjenden, er en selvfølge! « 8

Det kan tilføjes, at - af alle dage - fandt optællingen af stemmerne sted i Augustenborg netop den 18. april 1864, dagen hvor Dybbøl blev stormet af preusserne. ${ }^{9}$ Fra Augustenborg var der kun ganske få kilometer til krigsskuepladsen på den anden side af det smalle Alssund.

Scenen i denne fremstilling er hermed sat med krigen som det dystre bagtæppe for valgene.

\section{Rigsråd og Rigsdag}

Valgene til Rigsrådet blev udskrevet i henhold til Grundloven af 18. november 1863 for Kongeriget Danmarks og Hertugdømmet Slesvigs fælles Anliggender, kaldet Novemberforfatningen. Den trådte i kraft den 1. januar 1864. Rigsrådet bestod af Rigsrådets folketing og Rigsrådets landsting. De fælles anliggender var områderne under Udenrigsministeriet, Krigsministeriet, Marineministeriet og Finansministeriet. Denne nærmere knytning af Slesvig til Danmark blev af de tyske stormagter betragtet som et brud på aftalerne og de danske løfter fra 1851-1852 om den indbyrdes stilling mellem kongeriget Danmark og hertugdømmerne Slesvig og Holsten og Lauenborg og udgjorde den formelle begrundelse for Preussen og Østrig til at besætte Slesvig. ${ }^{10}$

Rigsrådet må ikke forveksles med Rigsdagen, der blev oprettet med Danmarks Riges Grundlov af 5. juni 1849. Rigsdagen bestod af Rigsdagens folketing og Rigsdagens landsting. Junigrundloven var oprindelig tænkt også at skulle gælde Slesvig, men under politisk stormagtspres blev denne tanke opgivet som farbar vej allerede i 1852, hvilket skete med den såkaldte Januarkundgørelse af 28. januar 1852, der udmøntede de danske løfter. ${ }^{11}$ Hermed var grænsebommen for Junigrundloven reelt gået ned ved Kongeåen. ${ }^{12}$ Først knap fire år senere indskrænkes Junigrundloven formelt gennem en grundlovsændring til kun at gælde kongeriget Danmark. ${ }^{13}$ Junigrundloven var dog gældende i de kongerigske enklaver i den vestlige del af Slesvig. ${ }^{14}$ 

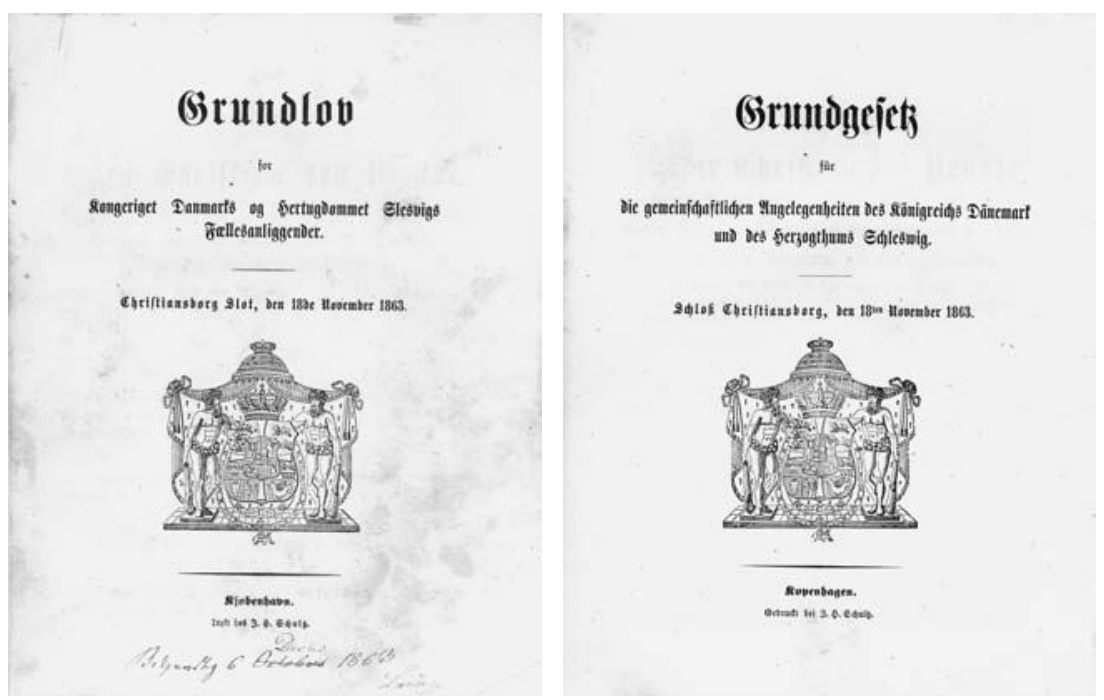

Novemberforfatningen, der var den formelle årsag til krigen $i$ 1864, ses her t.v. $i$ en danskproget udgave påført kvittering for bekendtgørelse den 6. december 1863 ved Laursen. Han var degn ved Tranderup kirke på Æ̈r. Den tysksprogede udgave lå $i$ arkivet sammen med den danske og har ikke nogen påtegning. Ærø var dansksproget. Foto: Marstal Søfartsmuseeum.

Pr. 1. januar 1864 var der således to grundlove. Danmark var omfattet af dem begge og Slesvig af den ene. De særligt kongerigske anliggender var områderne under Indenrigsministeriet, Kultusministeriet og Justitsministeriet. ${ }^{15}$ Det skulle vise sig, at der ikke var noget vandtæt skot mellem de to parlamenter. Af Rigsrådets 213 pladser var 92 besat med medlemmer, der også sad i Rigsdagen. ${ }^{16}$ Der var i alt 165 kongerigske pladser i Rigsrådet. ${ }^{17}$

For at tegne forfatningsbilledet færdigt pr. 1. januar 1864 skal det endelig nævnes, at de lokale forhold i hertugdømmet Slesvig blev reguleret af Forordning af 15. februar 1854 angående Hertugdømmet Slesvigs Forfatning. Der var på ingen måde tale om en liberal og demokratisk forfatning i stil med Junigrundloven. ${ }^{18}$

\section{Optakten til valget}

Samtidig med udskrivelsen af valget til Rigsrådet den 31. januar indstillede regeringen til kongen, at valgloven ændredes med henblik på at forkorte tidsfristerne ved udfærdigelse af valglister med mere. ${ }^{19}$ 
Ændringen af valglovens tidsfrister blev begrundet med, at Rigsrådet med de gældende tidsfrister m.m. næppe ville kunne træde sammen før tidligst i midten af april. Videre hed det: »Det behøver imidlertid næppe at udvikles, at det kunne træffe sig ønskeligt at Rigsrådet sammentræder tidligere. ${ }^{20}$ I en forestilling til kongen samme dag om udskrivelsen af valgene til Rigsrådet strammer D.G. Monrad, konseilspræsident og finansminister, formuleringen: "Som jeg har berørt i min allernådigste forestilling dags dato angående en foreløbig lov [...] vil det kunne blive særdeles ønskeligt, at Rigsrådet snart sammentræder. $\ll^{21}$

Hvad der præcist ligger i disse bemærkninger, meddeles der intet yderligere om, men begivenhederne midt i januar havde medført, at regeringen siden den 21. januar nu havde erklæret sig rede til at indkalde Rigsrådet med henblik på ophævelse af Novemberforfatningen i håb om at kunne undgå krigen. ${ }^{22}$

Set i det lys, giver det god mening at ændre valgloven med henblik på at få valget gennemført i en fart. Med udgangen af året 1863 var funktionsperioden for det tidligere rigsråd nemlig ophørt, og der var ikke gennem valg etableret noget nyt rigsråd, der i givet fald ville kunne træde sammen straks. Det fik betydning i forbindelse med de tyske stormagters ultimatum af 16. januar. Man forlangte her, at Danmark inden 48 timer skulle trække Novemberforfatningen tilbage, ellers ville man træffe foranstaltninger til at genoprette den tidligere tilstand, hvilket kun kunne betyde krig. Det danske svar var afvisende, idet man ikke på så kort tid på lovlig vis ville kunne nå at ophæve forfatningen. Man manglede simpelthen det organ, som i givet fald på lovlig vis kunne ændre eller måske endog ophæve den allerede vedtagne lov, medmindre man ville begå statskup ved straks at ophæve Novemberforfatningen på trods af alle konstitutionelle regler om, at det eneste organ, der retmæssigt kunne foretage ændringer, var Rigsrådet selv. ${ }^{23}$ De tyske stormagter krævede netop en sådan ophævelse og bekymrede sig ikke om de danske overvejelser om, hvordan det skete, bare det skete. ${ }^{24}$

På grund af den danske afvisning ophørte den direkte diplomatiske forbindelse mellem Danmark og de to tyske magter, og deres gesandter forlod København den 18. januar. Forhandlinger med de engelske udsendinge bibragte imidlertid danskerne den - fejlagtige - opfattelse, at man ved hurtigst muligt at afholde valg, indkalde det nyvalgte Rigsråd og forelægge det et forslag til ophævelsen af Novemberfor- 
fatningen, kunne afværge den truende krig. Den 21. januar informerede ministeriet de danske gesandter i London, Paris, Skt. Petersborg og Stockholm om, at man nu i modsætning til tidligere var villig til at lade udskrive valg til Rigsrådet med henblik på at forelægge det forslag til ophævelse af Novemberforfatningen. ${ }^{25}$ Det faldt i meget god jord hos det engelske diplomati, der dog, som det skulle vise sig, intet kunne udrette over for de tyske magter. På denne baggrund bliver det forståeligt, at man fra dansk side traf foranstaltninger til at fremskynde processen gennem en ændring af valgloven. Det var dog forgæves. Allerede dagen efter valgets udskrivelse i henhold til den nye valglov overskred de tyske tropper Ejderen, hertugdømmet Slesvigs sydgrænse, og krigen var en realitet.

Den tid, man havde vundet gennem den nye valglovs kortere tidsfrister, blev nu uden betydning. I realiteten havde tidsgevinsten kun drejet sig om forholdsvis få uger, nemlig forskellen på »tidligst i midten af april« og et tidspunkt, der nu kom til at ligge efter den 29. marts, datoen for valget til landstinget. Begrundelsen for at ændre valglovens frister havde jo været, at Rigsrådet ellers tidligst kunne træde sammen i midten af april. Nu kunne det så tidligst blive efter den 29. marts. I det lys kan det undre, at der gik en halv snes dage fra den 21. januar, til det åbne brev om valget så dagens lys den 31. januar. En forklaring kunne være, at man først skulle have afklaret spørgsmålet om, hvem der i Slesvig skulle stå for affattelsen af valglisterne. Den rolle, sogneforstanderskaberne spillede i kongeriget i forbindelse med et valg, kunne nemlig ikke uden videre overføres til Slesvig, hvor man ikke havde sogneforstanderskaber. Finansministeriet havde dog af egen drift »tyvstartet« processen. Ifølge valgloven skulle valglisterne til folketinget affattes og berigtiges i de sidste 14 dage af februar. Selv under normale forhold ville tiden nu være knap. Derfor henvendte man sig for en sikkerheds skyld den 16. januar til Ministeriet for Hertugdømmet Slesvig og udbad sig indstillinger om, hvilke autoriteter der i hertugdømmet skulle stå for udfærdigelsen af valglisterne og for folketingets vedkommende tillige skulle fungere som valgbestyrelse. ${ }^{26} \mathrm{Nu}$ gik det stærkt, og januars anstrengelser endte med en kongelig resolution den 26. januar om fastsættelse af valgbestyrelser for folketinget og en kongelig resolution den 3. februar om affattelse af valglister for landstinget. ${ }^{27}$

Efter 1. februar var virkeligheden en anden og det meste af Slesvig besat. Ikke desto mindre var valget sat i gang, og det blev trods alt 
gennemført på trods af krigstilstanden, men ikke med den hast, der var lagt op til, og ikke uden forhindringer. Tidsfaktoren spillede nu ikke længere den samme rolle. $\mathrm{Nu}$ drejede sig om at få valget gennemført. Besættelsen medførte samtidig, at valgene naturligvis ikke kunne gennemføres i alle valgkredse. Den fjendtlige besættelse først af det meste af Slesvig og senere dele af Jylland skulle komme til at afspejle sig i valgenes gennemførelse, resultater eller mangel på samme.

\section{Valgene i Slesvig og i Danmark (Jylland) til Rigsrådets folketing}

I hertugdømmet Slesvig blev det kun muligt at afholde valg til Rigsrådets folketing i tre ud af 28 folketingsvalgkredse, nemlig Sønderborg by, Als og Ærø. ${ }^{28}$ Der var i alt 29 pladser, idet en enkelt kreds, Flensborg med Glücksborg, havde to pladser. Det vil sige, at kun tre ud af 29 pladser blev besat. Det svarer til, at kun ca. ti \% af pladserne blev besat.

Selv hvor det var muligt at afholde valg, var krigstilstanden en særdeles nærværende virkelighed. Kort efter krigens udbrud fik borgmester Finsen i Sønderborg tilladelse til at udtræde af valgbestyrelsen i Rigsrådets folketings 4. slesvigske købstadsvalgkreds (Sønderborg), fordi »den aktive armés indkvartering i byen [...] for ham som borgmester og politimester [medfører] så mange og besværlige forretninger $\ll .{ }^{29}$

Krigen mærkedes, hvad folketingsvalgene angik, ikke bare i Slesvig, men også i kongeriget, men dog ikke nær så meget. Her blev næsten alle valg til Rigsrådets folketing gennemført, idet kun Vejle Amts 2. kreds (Kolding) skilte sig ud, fordi valget ikke kunne foretages "på grund af den fjendtlige okkupation «. ${ }^{30}$ Preusserne havde besat Kolding og omegn allerede den 18. februar.

I Ribe Amts 5. folketingsvalgkreds meddelte valgbestyrelsesformanden den 5. marts, at han så sig nødsaget til at sende sin indberetning via Ribe Stiftamt i stedet for direkte til Finansministeriet, »da postruten til hovedstaden over Løgumkloster og Aabenraa på grund af den fjendtlige besættelse ikke kunne benyttes «. ${ }^{31}$ Valgkredsen omfattede de kongerigske enklaver i Slesvig og kaldtes også Bredebrokredsen. 


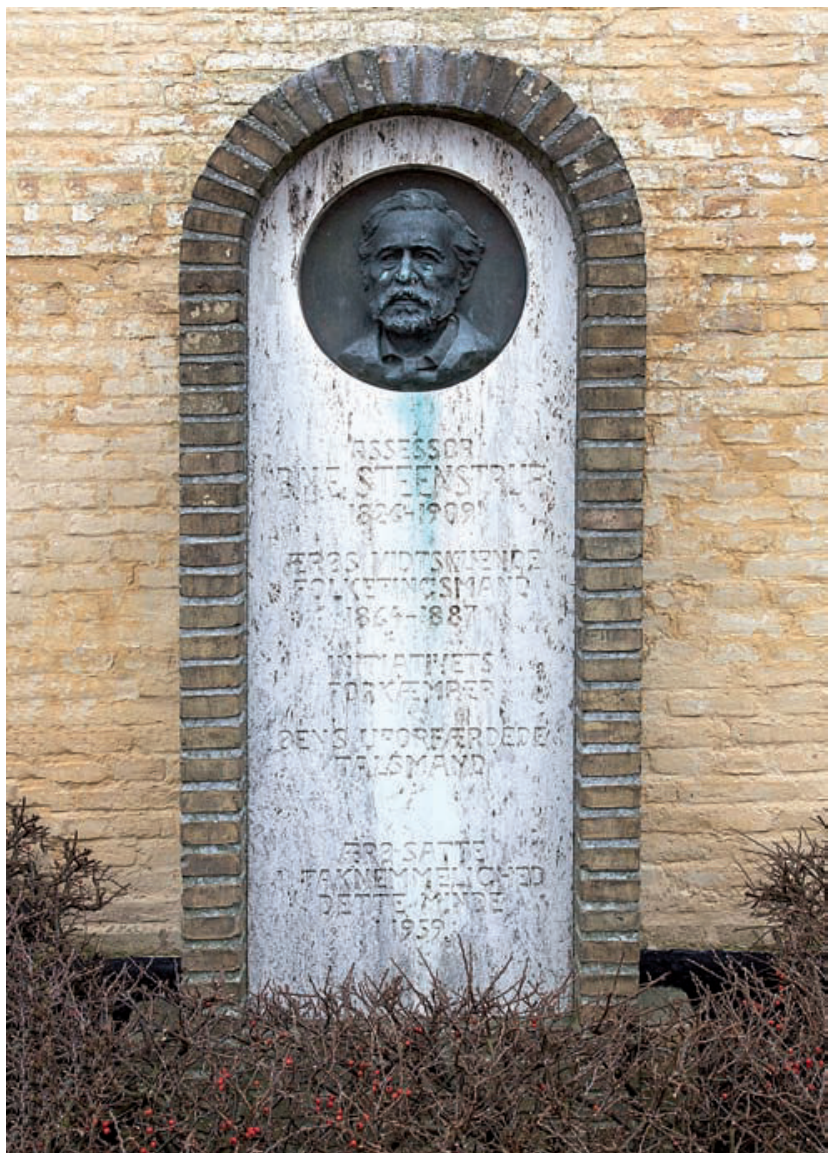

Minde på torvet i Ærøskøbing over assessor B.N.E. Steenstrup (1826-1909). Ærøs folketingsmand 1864-1887. Begyndte sit virke som folketingsmand i Rigsrådet $i$. blandede slesvigske kreds, dvs. Ærø og købstaden Ærøskøbing. Foto: Jens Lindholm.

De folketingsvalg, der blev gennemført, lykkedes det at afholde på selve dagen, nemlig den 5 . marts.

\section{Valgene i Danmark (Jylland) til Rigsrådets landsting}

I landstingskredsene måtte valgene i flere tilfælde udsættes til en senere dato end den 29. marts, men hver gang efter forud indhentet tilladelse. Det er i det hele taget karakteristisk, at man hele tiden foretog de nødvendige ændringer af regelsættet, således at der konstant 


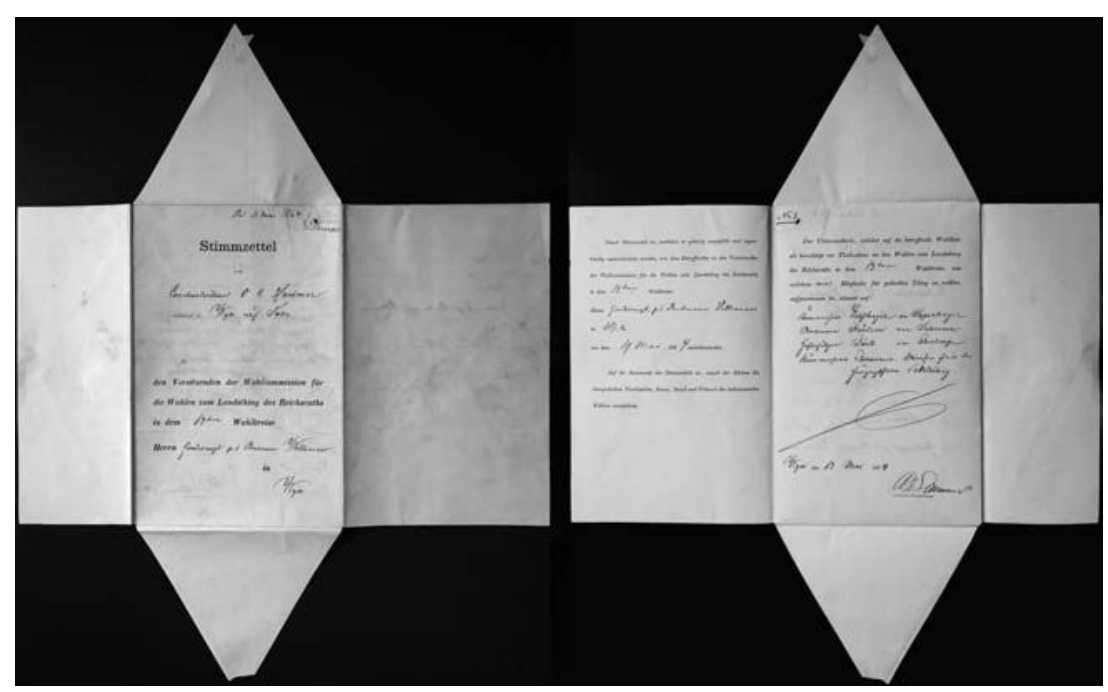

Stemmeafgivning til landstinget foregik pr. brev. Her stemmeseddel udfyldt af O.C. Hammer $i$ 13. landstingsvalgkreds.

På stemmesedlens side to ses navnene på de fire personer, der er stemt på. Der var ikke hemmelig afstemning. RA. Ministeriet for Hertugdømmet Slesvig. Sekretariatet. Sager angående Rigsrådet og valg til dette.

Valgene til folketinget skete derimod ved personligt fremmøde på et nærmere fastsat sted og tidspunkt og foregik ved kåring eller, hvis det begæredes, ved navneopråb. Foto: Jonas Vest.

kunne henvises til en hjemmel for de afvigelser, der grundet krigstilstanden måtte finde sted i henhold til det oprindelige regelsæt. Valgene blev gennemført efter bogen.

Den 8. marts blev stiftamtmanden i Ribe fritaget for sit hverv som formand for valgbestyrelsen i Rigsrådets landstings 11. kreds med valgsted i Varde med den begrundelse, at hans situation var meget vanskelig, fordi de fjendtlige tropper stod uden for Ribe, og en besættelse af byen ikke ville være usandsynlig. Det var ikke uden grund, blev det meddelt, at de kongerigske embedsmænd følte sig presset af situationen, idet man var bekendt med, at f.eks. herredsfogeden i Lø Herred var blevet arresteret og bortført. Der var derfor god grund til at tage bestik af situationen i tide og dermed så vidt muligt sikre sig, at valgene kunne gennemføres. Varetagelsen af hvervet som formand for valgbestyrelsen i 11. kreds blev herefter flyttet nordpå til amtmanden i Ringkøbing. ${ }^{32}$ Men forholdene var under hastig forandring.

Den 23. marts bemyndigedes amtmanden i Ringkøbing nemlig nu 
til i givet fald at beskikke en anden kongelig embedsmand i sit sted, fordi amtet muligvis kunne blive besat, og han således kunne komme til at lide samme skæbne som andre amtmænd, nemlig at blive bortført og dermed forhindret $i$ at fungere som formand for valgbestyrelsen. Desuden bemyndigedes han til, hvis det blev nødvendigt, dvs. hvis Varde skulle blive besat af fjenden, at flytte valgstedet fra Varde til et andet sted inden for valgkredsen. ${ }^{33}$ For klarhedens skyld bør det i denne sammenhæng bemærkes, at valgsted i forbindelse med valg til Rigsrådets landsting betegner stedet for optællingen af de indkomne stemmer, idet man stemte pr. brev. Overøvrighederne udsendte en stemmeseddel direkte til den valgberettigede, som returnerede stemmesedlen til valgbestyrelsen, der på en i forvejen bekendtgjort dag talte stemmerne op i offentlighed. Vælgeren kunne anføre lige så mange navne på stemmesedlen, som der skulle vælges kandidater $\mathrm{i}$ valgkredsen. For fremgangsmåden af optællingen gjaldt helt bestemte og meget detaljerede regler; når der på stemmesedlen måtte anføres et antal navne op til det antal, der skulle vælges i kredsen, så var det ikke helt enkelt. Det kunne gavne at gøre sig visse valgtaktiske overvejelser. ${ }^{34}$ Det var bl.a. derfor, at den i indledningen nævnte Jørgen Hansen ønskede, at vælgerne skulle levnes tid, så de kunne sætte sig ind $\mathrm{i}$, hvordan man gjorde.

Fjendtlighederne mærkedes også mod øst i Rigsrådets landstings 10. kreds, hvor Vejle var fastsat som sted for valghandlingen og amtmanden formand for valgbestyrelsen. Men den 9. marts kunne amtmanden i Skanderborg indberette til Finansministeriet, at forbindelsen til Vejle var blevet afbrudt, og den af valgloven foreskrevne fremsendelse af valglister til valgbestyrelsen i Vejle derfor foreløbig stoppet. ${ }^{35}$ Den 21 . marts blev byfogeden i Skanderborg ved kongelig resolution beskikket som formand for valgbestyrelsen i 10 . landstingsvalgkreds i stedet for amtmanden i Vejle, der var blevet bortført i fjendtligt fangenskab. ${ }^{36}$ Han blev samtidig bemyndiget til at lægge valgstedet hvor som helst inden for kredsens grænser. Han blev imidlertid også bortført. Derfor beskikkedes nu birkedommeren i Frijsenborg-Faurskov birk i stedet for. ${ }^{37}$ Den 18. april, samme dag som Dybbøl faldt, meddelte han, at han på trods af, at der manglede valglister fra 18 kommuner i Vejle Amt og én i Skanderborg Amt, havde fastsat valgdatoen til den 12. maj og ikke havde kunnet fastsætte den til en tidligere dag, fordi stemmesedlerne ikke ad ordinær vej havde kunnet komme vælgerne i hænde og derpå blive returneret, fordi størstedelen 


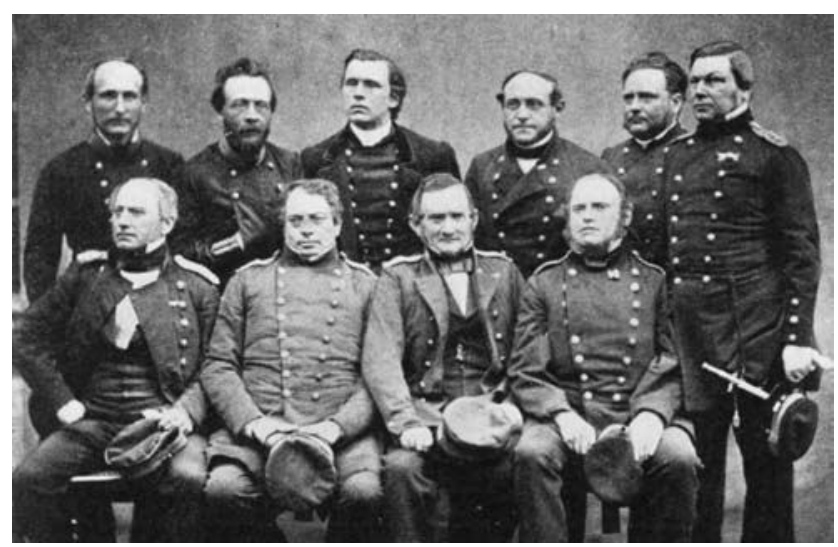

Frngslede jyske embedsmænd $i$ Rendsborg. Foto 1864. Fra venstre, siddende: C.B.A. Dahl [amtmand $i$ Vejle], T.C. Dahl [stiftamtmand i Aarhus], H.C. Nielsen [stiftamtmand $i$ Ribe], I C. Bille-Brahe [amtmand i Skanderborg]; stående: A.F. Bülow [byfoged $i$ Skanderborg], A.S. Ørsted [byfoged $i$ Vejle], A.P.Th. Meinert [borgmester $i$ Ribe], M.A. Monrad [borgmester i Kolding], J.A.F. Bagger [byfoged i Varde], I C. $v$. Jessen [borgmester $i$ Horsens]. von Jessen 1943, s. 63.

af Vejle Amt endnu var besat af fjenden. Det blev samtidig meddelt, at et nærmere angivet antal stemmesedler dog havde kunnet udsendes. ${ }^{38}$

Billedet var det samme en anelse længere nordpå. Her nåede fjenden at tangere 9. landstingsvalgkreds, der strakte sig fra Randersområdet til syd for Aarhus. Her fik formanden for valgbestyrelsen, amtmanden i Randers, den 15. marts tilladelse til at udsætte valghandlingen. Han anførte, at Horsens og muligvis Skanderborg var blevet besat. Telegraflinjen dertil var blevet afbrudt. Desuden havde fjenden kortvarigt været i den sydlige del af Århus Amt, som grænsede op til Skanderborg. Denne del af valgkredsen afhentede oven i købet sin post i Horsens, der altså nu var blevet besat. I sin skrivelse understregede Finansministeriet det ønskelige i, at valget kunne afholdes på den officielle dag, og efter ikke at have undladt at foreslå anvendelse af særlige bud overlod Finansministeriet dog spørgsmålet om en udsættelse til amtmandens konduite. Men det skulle være så nær den oprindelige dag som muligt. ${ }^{39}$

Der blev således på trods af situationen utrætteligt truffet foranstaltninger til, at valgene skulle kunne gennemføres. Nord for Kongeåen blev valgene til Rigsrådets landsting da også virkelig gennemført. På øerne var der selvsagt ikke de samme vanskeligheder med at gennemføre valgene, som i de af krigen prægede områder af Jylland. 


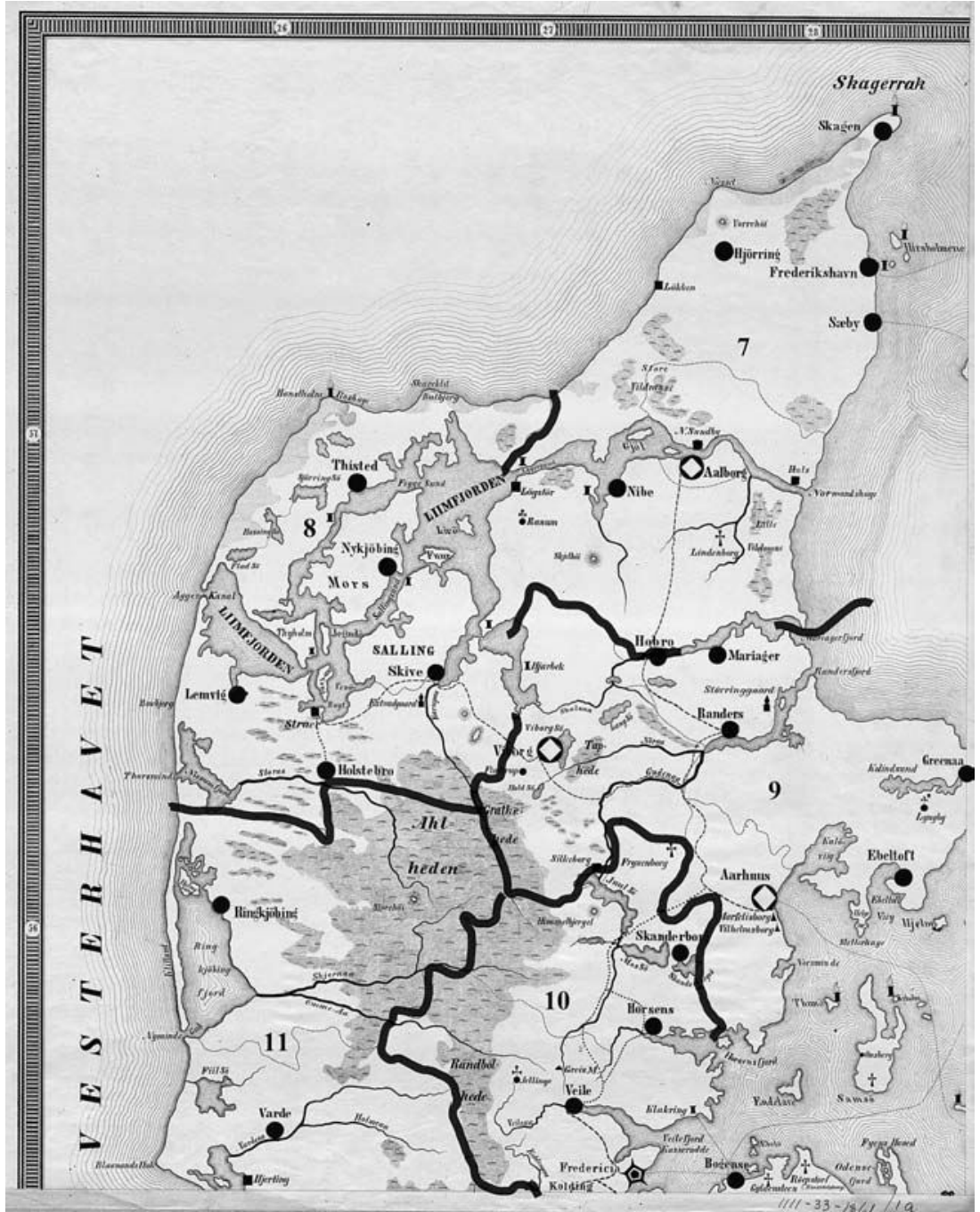

De nørrejyske landstingsvalgkredse omtrentligt indtegnet af denne artikels forfatter på foto af Skole-Kort over Danmark med Hertugdömmerne Holsten og Lauenborg Til Brug i Borger- og Almueskoler samt private Instituter, Odense 1861. Den præcise inddeling fremgår af valgloven af 4. december 1863. Foto: Det Kongelige Bibliotek.

I Rigsrådets 10. landstingsvalgkreds blev den offentlige valghandling først gennemført så sent som den 3. juni. Den havde således måttet udskydes endnu en gang. ${ }^{40}$ Det betød til gengæld, at man ikke blot 
havde fået mulighed for at udsende endnu flere stemmesedler end i første omgang, men også alligevel at benytte Vejle som valgsted. ${ }^{41}$ Der må være sket noget i mellemtiden! Der var sket det, at en våbenhvile var trådt i kraft fra 12. maj gældende for en måned. Blandt betingelserne hørte netop, at kommunikationen og administrationen skulle forløbe regelmæssigt i de besatte områder.

I Rigsrådets 11. landstingsvalgkreds blev det alligevel amtmanden i Ringkøbing, der endda på selve datoen gennemførte den offentlige valghandling den 29. marts, dog ikke i Varde, fordi fjendtlige tropper flere gange havde været $\mathrm{i}$ byen og stadig strejfede omkring og truede byen med besættelse, hvis de forlangte udskrivninger ikke blev nøje efterkommet. ${ }^{42}$ I stedet blev valghandlingen efter forudgående annoncering i aviserne i Ribe, Varde og Ringkøbing forlagt til Ringkøbing. ${ }^{43}$

Valget i Rigsrådets 7. landstingsvalgkreds afholdtes med en lille forsinkelse den 6. april i Aalborg. ${ }^{44}$ Her skyldtes forsinkelsen dog slet ikke krigsforholdene, men problemer med valglisterne. ${ }^{45}$

I Rigsrådets 9. landstingsvalgkreds blev valget med godt to ugers forsinkelse afholdt i Randers den 14. april. ${ }^{46} \mathrm{Nu}$ manglede der af de nørrejyske kredse kun ovennævnte 10. valgkreds. ${ }^{47}$

Af ovenstående kan man se, hvorledes krigens påvirkning af valgenes gennemførelse rykkede længere og længere nordpå, men gennemført blev de - om end med forsinkelse.

Efterhånden som begivenhederne udviklede sig, blev fokus for regeringen flyttet fra at få valgene gennemført hurtigt til i det hele taget at få dem gennemført - så vidt muligt. Krigen var en kendsgerning, og situationen var i løbet af februar blevet en helt anden, end da valgene blev udskrevet. Og det på flere måder. Der var ikke bare blevet krig, men der var også dårligt vejr. Vinteren holdt landet i et jerngreb. Det gjorde bestemt ikke vanskelighederne mindre, men man gjorde i det hele taget alt for at få valgene gennemført. Det ses af den kongelige resolution af 24 . februar om ændring af den allerede én gang ændrede valglov. Finansministeren bemyndigedes her til at foretage ændringer i tidsbestemmelser og valgdage, fordi man vanskeligt under de givne omstændigheder kunne overholde de fastsatte tidsfrister. ${ }^{48}$ Set i bakspejlet er regeringens begrundelse for lovændringen interessant, ja nærmest underspillet, idet der som indledning henvistes til den forstyrrelse, som naturforholdene og »andre omstændigheder«(!) havde medført i kommunikationen med de fra hovedstaden fjernere beliggende dele af landet. 
Ikke en gang fire uger efter man havde ændret valgloven med henblik på at fremskynde valgene, måtte man nu slække skødet. Denne resolution fik betydning for afholdelse af valgene i landstingskredsene, idet valgene i folketingskredsene, i det omfang de fandt sted, blev afholdt planmæssigt den 5. marts.

Det lykkedes således under de vanskelige forhold med krig og besættelse at få gennemført valgene i kongeriget til Rigsrådets landsting.

\section{Valgene i Nørrejylland til Rigsrådets landsting og krigens geografi}

Den 18. februar rykkede preussiske styrker ind i Kolding. Dermed havde man overskredet grænsen til kongeriget, og krigen var dermed ikke længere begrænset til hertugdømmet Slesvig. ${ }^{49}$ Besættelse af Kolding og omegn var årsagen til, at der ikke kunne foretages valg til Rigsrådets folketing i 2 . valgkreds (Koldingkredsen) den 5. marts.

Man rykkede dog ikke videre frem i denne omgang. De tyske stormagter var ikke enige om retningen for felttoget. Preusserne ville føre krigen op i Nørrejylland, mens østrigerne ville gå mod Dybbøl. Det tog et stykke tid at blive enige, men det blev den preussiske strategi, man enedes om.

Først den 8. marts rykkede de allierede tyske styrker derfor for alvor videre op i Jylland, hvor det kom til kamp ved Vejle. Horsens blev besat den 10. marts. Man var kortvarigt i Århus den 13. marts, men faldt ellers tilbage til området syd for Skanderborg.

Hermed var forbindelsen mellem Skanderborg og Vejle afbrudt, hvilket fik betydning for forberedelserne af valget til Rigsrådets landsting i 10. kreds, der omfattede Vejle og Skanderborg Amter. Desuden blev den sydlige del af 9. landstingskreds berørt. Den bestod af Randers Amt, Viborg Amts østlige halvdel og Århus Amt.

Først da Dybbøl var faldet den 18. april og Fredericia rømmet den 28. april, rykkede de tyske styrker for alvor op i Jylland og nåede Aalborg den 5. maj. På det tidspunkt var valgene i Rigsrådets jyske landstingsvalgkredse for længst afgjort. Undtagen et sted, nemlig i 10. kreds. Her blev valget afholdt $i$ Vejle den 3. juni under våbenhvilen. ${ }^{50}$ Våbenhvilen varede fra 12. maj til 26. juni efter at være blevet forlænget med 14 dage. Imens foregik der intense forhandlinger i London, indtil danskerne - med datidens sprogbrug - »sprængte konferen- 
cen«, og krigen blev genoptaget med preussernes overgang til Als den 29. juni.

\section{Valgene i Slesvig til Rigsrådets landsting}

I de tre slesvigske landstingsvalgkredse blev otte ud af 13 pladser besat, svarende til ca. 61\%. Det var forholdsmæssigt langt flere end for folketingsvalgkredsenes vedkommende. Det var dog kun ved hjælp af et »håndgreb «, man nåede frem til at kunne få valgt så relativt mange - om overhovedet nogen - til landstinget.

Slesvig var inddelt i tre landstingsvalgkredse, som man for nemheds skyld kan betegne som et vestligt, et østligt og et sydligt. ${ }^{51}$ Til hver af disse kredse hørte nogle øer. Til 13. landstingsvalgkreds mod vest hørte de slesvigske dele af Sild, Før og Rømø, til 14. landstingsvalgkreds mod øst hørte Als og Ærø, og endelig hørte Femern og de sydligste af Vesterhavsøerne til 15. landstingsvalgkreds mod syd. ${ }^{52}$

Selv om Slesvigs fastland var blevet okkuperet, var øerne stadig under regeringens herredømme, og man fik den idé at lade vælgerne på disse øer vælge repræsentanterne for hele den valgkreds, de tilhørte. »Da Finansministeriet må anse det for ønskeligt, at der gives de indvånere i de af fjenden ikke okkuperede dele af hertugdømmet Slesvig, som er valgberettigede ved valgene til Rigsrådets landsting, lejlighed til ved de forestående valg at gøre brug af den dem tilkomne valgret, men dette for en del navnlig i henhold til lov angående valgene til Rigsrådet af 4. december $1863 \S \S 15$ og 17 er betinget af, at der for alle distrikter findes fungerende overøvrigheder, hvilket formentlig under de nuværende forhold ikke er tilfældet med hensyn til Vesterhavsøerne, har man ikke villet undlade tjenstligt at henvende sig til Det kongelige Ministerium [for hertugdømmet Slesvig] med anmodning om, at samme, efter omstændighederne snarest muligt behageligt ville træffe fornøden foranstaltning med hensyn til varetagelsen af overøvrighedsforretningerne for de nævnte øer så længe den nuværende tilstand på det slesvigske fastland vedbliver.

I forbindelse med ovenstående skulle man derfor tjenstligt anmode Det kongelige Ministerium om snarlig behagelig ytring med hensyn til hvilke medlemmer valgbestyrelserne for 13., 14. og 15. landstingskreds måtte kunne sammensættes af, samt hvilke valgsteder der måtte være at fastsætte. « ${ }^{53}$

Her har vi baggrunden for, at et i virkeligheden ringe antal vælgere 


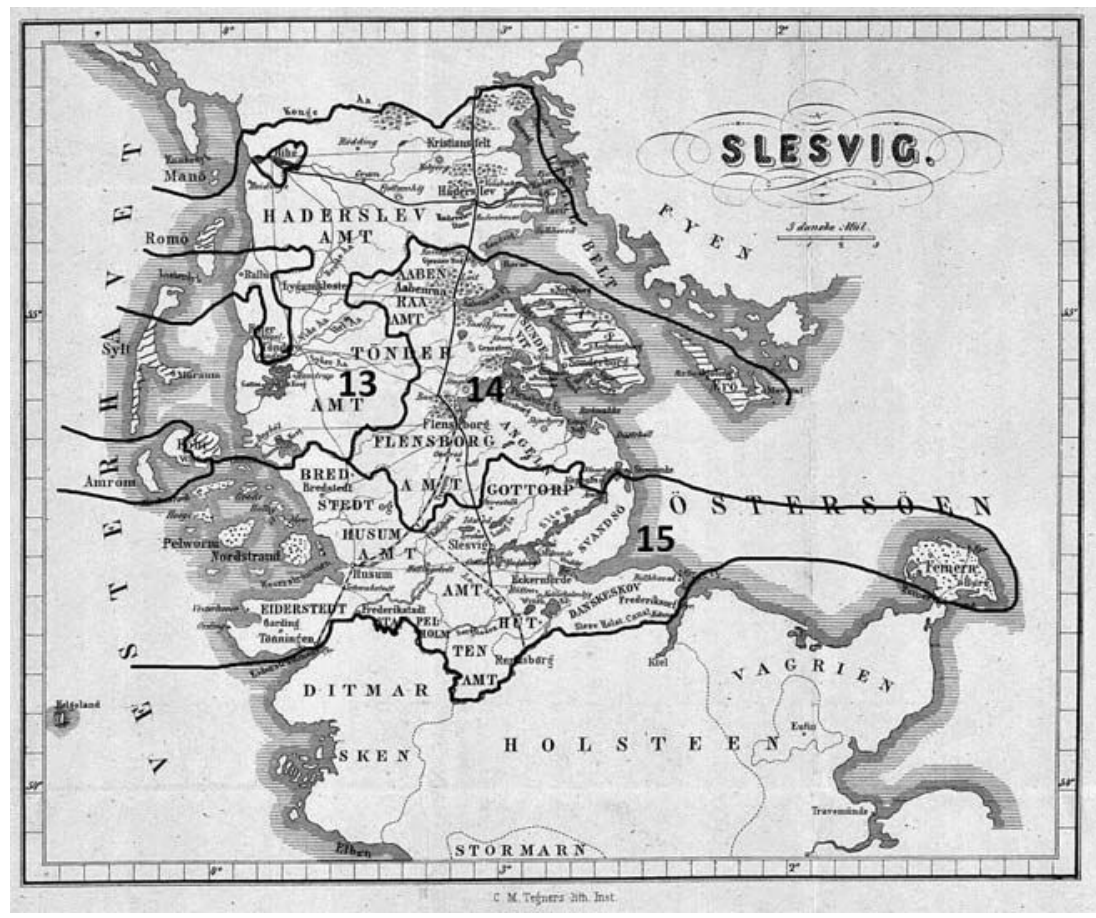

De tre slesvigske landstingsvalgkredse. De til hver kreds hørende øer er særskilt markerede. Vælgerne på øerne $i$ kreds 13 og 14 valgte samtlige kredsens medlemmer til Rigsrådet, fordi fastlandet var besat. Øerne i kreds 15 blev besat inden valgets afholdelse. Indtegnet omtrentligt af denne artikels forfatter på foto af kort af C.M. Tegner, 1864. Foto: Det Kongelige Bibliotek.

kom til at præge valgets resultat i uforholdsmæssig stor grad. Den nævnte overøvrigheds funktion i forbindelse med landstingsvalget var at udsende de berigtigede valglister til valgbestyrelserne, der herefter ligeledes gennem overøvrigeden skulle udsende stemmesedler til de valgberettigede. ${ }^{54}$

Det var en forholdsvis overkommelig opgave. Der var nemlig privilegeret valgret til Rigsrådets landsting. Kun en brøkdel af dem, der havde valgret til folketinget, kunne stemme, idet valgretten beroede på enten en vis skatteydelse eller en vis indtægt. Det indskrænkede vælgerskaren betragteligt.

På Femern havde man amtmanden som overøvrighed. ${ }^{55}$ På Als og Ærø havde man en konstitueret amtmand over Sønderborg-Nordborg 
Amter. ${ }^{56}$ På Vesterhavsøerne opfandt man en øvrighed med det "mundrette" navn Den Interimistiske Overøvrighed for Vesterhavsøerne, hvor den fordrevne herredsfoged A.Th. Villemoes fra Kjær Herred syd for Tønder blev udnævnt til at varetage overøvrighedsforretningerne, så længe det slesvigske fastland var besat. ${ }^{57}$

Noget tyder på, at man fra Ministeret for Hertugdømmet Slesvigs side også på dette tidspunkt regnede med gennemførelse af valg på de til 15. landstingskreds hørende sydlige Vesterhavsøer, nemlig Nordstrand, Pelvorm og Halligerne. I hvert fald varskoede man valgbestyrelsens formand i 15. landstingsvalgkreds provst Otzen på Femern om, at Den Interimistiske Overøvrighed for Vesterhavsøerne nu var blevet etableret. ${ }^{58}$

På denne måde stod man nu med tre miniamter med hver sin overøvrighed, således at der var en overøvrighed i hver af de endnu ubesatte stumper af de tre slesvigske landstingsvalgkredse. Man havde således de øvrigheder på plads, som valgloven forudsatte.

Ved kongelig resolution af 5. marts blev formændene for valgbestyrelserne og de tilforordnede for de tre slesvigske landstingskredse udnævnt i medfør af valglovens bestemmelse om, at valgbestyrelserne udnævntes af kongen. ${ }^{59}$ En uges tid tidligere var udnævnelsen sket for de 12 tilsvarende valgkredse i kongeriget. Nu var turen så kommet til Slesvig, men der måtte tages hensyn til krigstilstanden, idet finansminister D.G. Monrad som baggrund for sin indstilling udtrykkeligt anførte, at man havde peget på mænd, som befandt sig "uden for de dele af hertugdømmet, som er i fjendevold « ${ }^{60}$ Ved samme lejlighed blev de tre valgsteder fastsat. Formænd, tilforordnede samt valgsteder fremgår af følgende oversigt.

\section{3. landstingskreds (Haderslev, Tønder og Løgumkloster Amter). ${ }^{61}$} »Formand for valgbestyrelsen: Den Interimistiske Overøvrighed for

Vesterhavsøerne «.

»Tilforordnede: Postmester D.G. Hansen i Vyk og pastor Meier i Keitum «.»Valgsted: Vyk «.

14. landstingskreds (Åbenrå, Sønderborg, Nordborg og Flensborg Amter, Flensborg By og Kappel Herred).

»Formand for valgbestyrelsen: Biskoppen over Als og Ærø, Hansen«. »Tilforordnede: Rådmand Behn i Sønderborg og amtsforvalter, prem.lieutn. Wolf i Ærøskøbing «. $»$ Valgsted: Augustenborg «. 
15. landstingskreds (Bredsted og Husum Amter, Ejdersted, Gottorp, Hytten og Femern Amter og Egernførde Herred).

»Formand for valgbestyrelsen: Provst Otzen«.

»Tilforordnede: Amtsforvalter Massmann og diacunus Schmidt i

Landkirchen «.

»Valgsted: Burg«.

En måneds tid tidligere var Ministeriet for Hertugdømmet Slesvig uopfordret over for Finansministeriet fremkommet med et forslag om det samme og havde foreslået amtmændene over Haderslev, Flensborg og Gottorp/Hytten Amter som formænd. ${ }^{62}$ Det kunne der ikke blive tale om. Krigsudviklingen i løbet af februar måned havde gjort en forskel.

På grund af krigstilstanden var de tre slesvigske landstingsvalgkredse i begyndelsen af marts altså skrumpet ind til kun at omfatte de små områder af Slesvig, der endnu var under kontrol af den hidtidige kongelige regering, nemlig øerne. Samtidig blev der fra regeringens side udvist en vilje til at få rigsrådsvalget gennemført på trods af omstændighederne. På Femern overhalede begivenhederne imidlertid hurtigt de trufne foranstaltninger. Allerede en halv snes dage senere så billedet igen anderledes ud. Den 15. marts blev Femern besat, og amtmand Broder Knudsen taget til fange. ${ }^{63}$ Besættelsen gjorde det umuligt at gennemføre valget. ${ }^{64}$ De til samme 15 . landstingsvalgkreds hørende sydlige Vesterhavsøer var heller ikke længere under dansk kontrol. Da den konstituerede amtmand, A. Villemoes, tiltrådte sit embede i Vyk på Før den 18. marts, forefandt han »den kongelige myndighed kuldkastet på de til Husum-Bredsted Amt hørende Vesterhavsøer«, og den »tilstedeværende krigsmagt« følte sig endnu ikke stærk nok til at hævde herredømmet over disse øer, fordi der var blevet oprettet en folkevæbning til at forhindre »den lovlige styrelses genoprettelse $«{ }^{65}$ De nordlige Vesterhavsøer, Østerland-Før med Vyk og Sild, der alle lå i 13. landstingsvalgkreds, var derimod grundet Vesterhavsflotillens tilstedeværelse under kongelig kontrol. ${ }^{66}$

Der var nu kun to af de minimerede landstingsvalgkredse tilbage, og der blev gennemført valg i dem begge.

Valget i 14. landstingsvalgkreds blev gennemført på Als og Ærø den 18. april i Augustenborg. Det var samme dag, som Dybbølskanserne blev løbet over ende. Optællingen foregik til akkompagnement af kanontorden. Med biskop Hansens egne ord: »Valget foretoges [...] 
midt under stormen på Dybbøl - man vidste i København tidligere besked om udfaldet end vi, thi vi hørte ikke andet end kanonerne. « ${ }^{67}$ Der var i alt 326 vælgere i henhold til valglisterne. ${ }^{68}$ I Als Nørreherred 23, i staden Sønderborg 18, i Als Sønderherred fem, i Augustenborg Herred 259 og på Ærø 21.

Der indkom 236 stemmesedler. Valgt blev biskop J. Hansen, appellationsråd C. Knudsen, amtmand Heltzen og syns- og boelsmand H.C. Bladt. Valgbrevet til Heltzen blev det anset for umuligt at få tilstillet ham (amtmand i Aabenraa), hvorfor valgbestyrelsen vedtog at indsende det til Finansministeriet. ${ }^{69}$ Herfra blev det tilstillet ham den 9. juli. Igen havde krigen sat sit præg på valgets praktiske gennemførelse.

En sammenligning med nogle landstingsvalgkredse nord for Kongeåen med henblik på antallet af afgivne stemmer giver følgende resultat: 1. valgkreds, København med fire medlemmer, 481 stemmesedler udsendt, 314 returneret. 2. valgkreds, Københavns Amt, Frederiksberg og Holbæk Amt med otte medlemmer, 1774 stemmesedler udsendt, 1455 returneret. 3. valgkreds, Sorø og Præstø Amter med fem medlemmer, 660 stemmesedler udsendt, 578 returneret. 4. valgkreds, Bornholms Amt med ét medlem, 88 stemmesedler udsendt, 77 stemmesedler returneret. 10. valgkreds, Vejle og Skanderborg Amter med fire medlemmer, 481 stemmesedler udsendt og 314 returneret. $^{70}$ Forholdene på Als taget $\mathrm{i}$ betragtning, må stemmeandelen siges at være helt pæn.

Valget i 13. landstingsvalgkreds blev gennemført på Vesterhavsøerne den 24. maj 1864 kl. 10 på Redlefsens Hotel i Vyk på Før efter forudgående annoncering den 21. april i Berlingske Tidende og Ribe Stiftstidende. Valgdatoen måtte grundet forholdene også her fastsættes senere end den 29. marts. På dagen for Villemoes' udnævnelse den 7. marts godkendte Finansministeriet denne udsættelse - dog ikke længere end nødvendigt. ${ }^{71}$ På grund af »de vedvarende uregelmæssigheder i postforbindelsen mellem Vesterhavsøerne « havde valgdatoen ikke kunnet sættes tidligere end den 24 . maj. ${ }^{72}$

Der var i alt 32 vælgere i henhold til valglisterne. I den til Haderslev Amt hørende del af Rømø var der ingen vælgere, i den til Tønder Amt hørende del af Sild én vælger, og i den til Tønder Amt hørende del af Før (Før-østerland og Vyk) var der optaget 31 vælgere på valglisten. ${ }^{73}$

Der indkom ni stemmesedler. Valgt blev kammerherre Wolfhagen, København, gårdejer C. Juhl, Hjerndrup, amtmand Broder Knudsen 


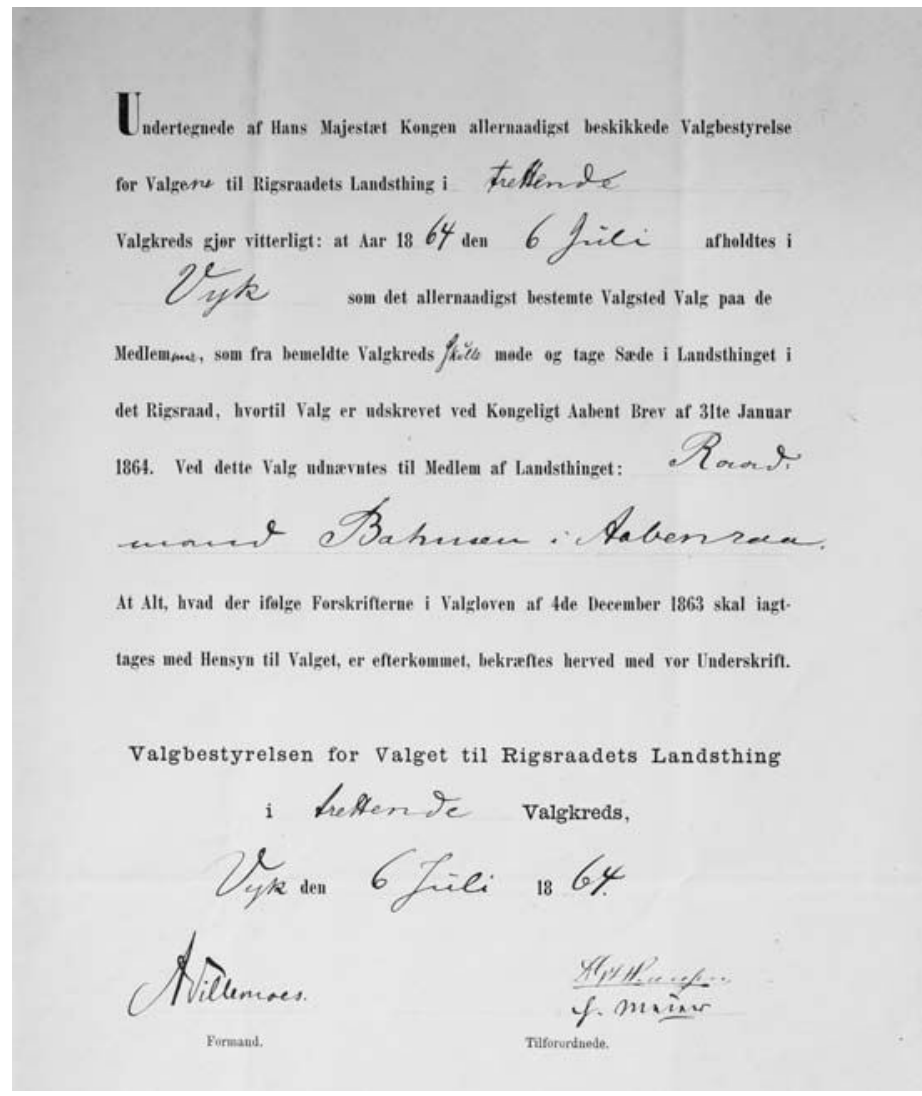

Martin Bahnsen (1809-1875) var rådmand i Aabenraa og blev afsat i 1864. Valgbrevet blev aldrig afhentet, men henligger stadig $i$ Finansministeriet. RA. Budgetdepartementet, Finansministeriets sekretariat: Rigsrådssager 1864-1865. Foto: Jonas Vest.

fra Femern, p.t. København, og kammerherre, minister for hertugdømmet Slesvig, W. Johannsen fra Husum, p.t. København. ${ }^{74}$

To af disse modtog dog ikke valget. Det var Christian Juhl ${ }^{75}$ og W. Johannsen. ${ }^{76}$ Finansministeriet anmodede derfor tjenstligt herredsfoged Villemoes om at foranledige suppleringsvalg afholdt. ${ }^{77}$ Dette iværksattes, og den offentlige optælling af stemmerne berammedes til den 6. juli. Der indkom denne gang 14 stemmesedler. ${ }^{78}$ Valgt blev kaptajnløjtnant O. Chr. Hammer, Vyk, og rådmand Bahnsen, Aabenraa, og valgbrevene blev udfærdiget. »Efter at valgbestyrelsen [...] har undertegnet valgbrevet for rådmand Bahnsen i Aabenraa, er det fun- 
det alt for betænkeligt at tilstille ham samme ad den uregelmæssige vej, ad hvilken jeg har søgt at bringe ham en meddelelse om valget $\mathrm{i}$ hænde. Jeg har derfor i den til ham desangående udfærdigede skrivelse underrettet ham om, at det vil blive ham udleveret på anfordring af Det kongelige Finansministerium, og tillader mig derfor ved at oversende bemeldte valgbrev ærbødigst at henstille, at det gunstigt må blive opbevaret og eventuelt afgivet til ham. «79

Det var imidlertid på et hængende hår, at man i Vyk havde fået gennemført suppleringsvalget i 13. landstingsvalgkreds. På dette tidspunkt, hvor også Als var gået tabt, kunne valget kun finde sted, fordi Vesterhavsflotillen under kommando af kaptajnløjtnant O.C. Hammer stadigvæk kunne hævde den danske myndighed på de nordlige Vesterhavsøer. Flotillen bestod af det uarmerede hjuldampskib Liimfjorden og otte kanonjoller (rojoller), en mindre dampbåd samt nogle lettere sejlfartøjer. ${ }^{80}$ Inden der var gået to uger, var det slut. Allerede den 13. juli besatte østrigerne Sild. ${ }^{81}$ Nettet strammedes om Før, og situationen blev uholdbar. Den 20. juli overgav Vesterhavsflotillen sig ganske få timer før den våbenstilstand, der reelt blev enden på krigen, trådte i kraft den 20. juli 1864 kl. 12. Af hele hertugdømmet Slesvig var nu kun Ærø på danske hænder.

Da suppleringsvalget blev afholdt, var Rigsrådet allerede trådt sammen, nemlig den 25. juni, og formanden i Rigsrådets landsting blev den 6. juli underrettet om udfaldet af valget, og Hammer og Bahnsen kunne indtage deres pladser. ${ }^{82}$ Hammer kunne dog ikke give møde "på grund af den ham anbetroede militære kommando på vestkysten af hertugdømmet Slesvig «.83 Af Rigsrådets arkiv kan det konstateres, at mens Hammer afleverede sit valgbrev til Rigsrådet, fik Bahnsen ikke afhentet sit valgbrev i Finansministeriet, i hvis arkiv det stadig henligger. Hans valgbrev har da heller ikke været til behandling i Rigsrådets landsting. Det kan kun betyde, at han ikke har kunnet indtage sin plads i Rigsrådets landsting.

I Rigsrådets landsting rejste der sig på foranledning af C.G. Andræ en debat $\mathrm{i}$ forbindelse med godkendelsen af de slesvigske medlemmers valgbreve. Det var ikke om valgbrevene i sig selv, heller ikke om hvorvidt de enkelte valg var foretaget efter forskrifterne, og heller ikke fordi der forelå nogen klage. Det drejede sig om hele baggrunden for valgene på de ubesatte øer. Kunne et valg nemlig betragtes som gyldigt for hele valgkredsen, når det kun var foretaget af vælgere $\mathrm{i}$ en lille del af kredsen? Det burde undersøges nærmere. Han gennem- 


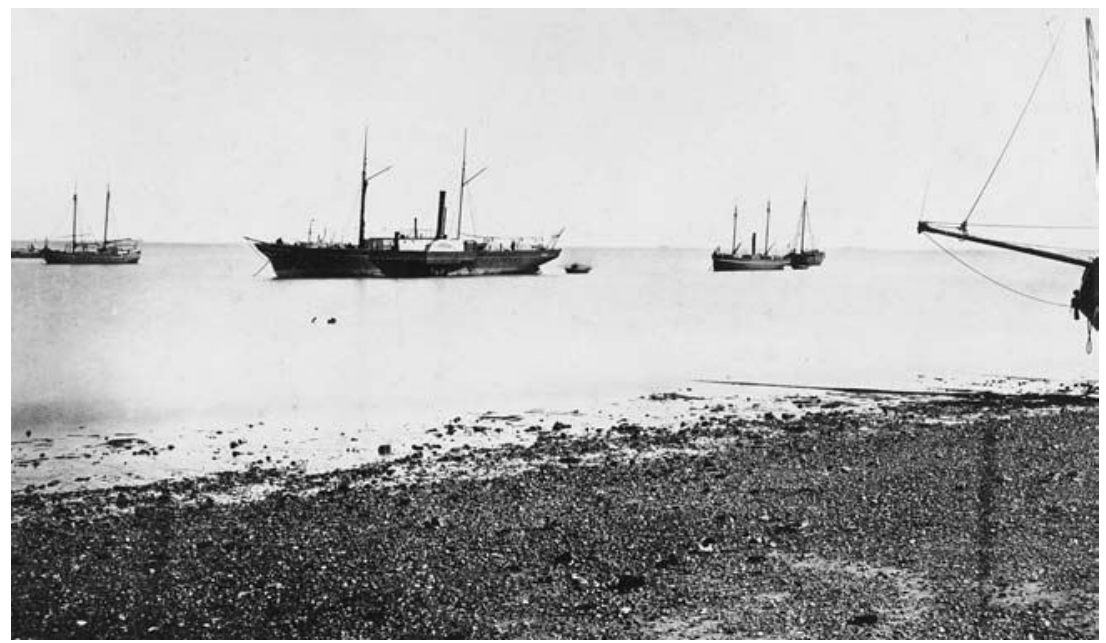

Vesterhavsflotillens tilstedeværelse var betingelsen for at valgene kunne afholdes $i$ Rigsrådets 13. landstingsvalgkreds. Hjulskibet Liimfjorden, Vesterhavsflotillens uarmerede flagskib, håndhævede med sin trækkraft sammen med 8 kanonjoller den danske myndighed på de nordlige vesterhavsøer. Billedet er taget ved Før. "Nach der Natur photographiert von F. Brandt in Flensburg." Bibliografi og Ikonografi 1864, nr. 5739. Foto: Det Kongelige Bibliotek.

førte debatten kompromisløst og stringent. Selv fremlagde han dog ikke nogen konkret løsning. Han blev imødegået af blandt andet D.G. Monrad, der påpegede, at det var ydre tvang, der var skyld i den nuværende situation, og at man ikke skulle ringeagte et resultat på baggrund af få stemmer, blot fordi det ikke har været muligt af afholde valg i hele kredsen med mange stemmer. J.N. Madvig anførte, at det ville være at give fjenden indflydelse på vore borgerlige rettigheder, hvis man anfægtede de foretagne valg. C.G. Andræ blev kun støttet af et lille mindretal, og valgbrevene blev godkendt. ${ }^{84}$ Debatten var et sammenstød mellem den teoretiske og den praktiske virkelighed. Debatten om valgbrevene viser, at der også i samtiden var nogle - om end få - der havde øje for den særprægede konstruktion med de »amputerede« valgkredse.

\section{Rigsrådet indkaldes}

I åbent brev af 13. juni 1864 indkaldtes Rigsrådet i henhold til Novemberforfatningen til en overordentlig (ekstraordinær) samling, som 
blev det nyvalgte Rigsråds første. Den skulle finde sted den 25. juni. På tidspunktet for indkaldelsen var den forlængede våbenhvile stadig i kraft, og stormagtsforhandlingerne i London var stadig i gang. Våbenhvilen var trådt i kraft den 12. maj og løb til den 26. juni efter at være blevet forlænget med 14 dage. ${ }^{85}$

I begyndelsen af juni mente regeringen, at tiden nu var kommet til, at Rigsrådet skulle sammenkaldes. Det burde ikke udskydes længere. Der var nemlig i første halvdel af 1864 blevet gennemført en del foreløbige love, som det nu var på tide at få Rigsrådets samtykke til. ${ }^{86}$ Det drejede sig a) om ændringerne den 31. januar om afkortelsen af valglovens tidsfrister, b) om bemyndigelsen den 21. februar til Finansministeriet om at tillade fravigelser af denne lov og c) om krigsskat den 19. februar på brænderidriften og vareindførselen.

Desuden havde gehejmestatsrådet den 19. marts truffet beslutning om at anvende en del af et - før krigen - optaget lån til afholdelse af nødvendige udgifter grundet krigsforholdene. En sådan beslutning om øgede udgifter krævede efterfølgende godkendelse af Rigsrådets folketing. ${ }^{87}$ Hertil kom de øjeblikkelige politiske forhold. Skulle det ende med en fredsslutning, blev Rigsrådets samtykke formentlig nødvendigt. Skulle det derimod komme til en fortsættelse af krigen, ville regeringen ikke påtage sig ansvaret for de øgede udgifter, uden de havde været forelagt Rigsrådet. Regeringen anbefalede derfor, at Rigsrådet sammenkaldtes til den 14. juni. ${ }^{88}$

Forestillingen opnåede dog aldrig kongelig approbation. Men sagen lå langt fra stille. En sammenkaldelse af Rigsrådet havde åbenbart været forelagt de danske forhandlere i London, sandsynligvis med henblik på en sondering af om en sammenkaldelse ville forstyrre forhandlingerne. I hvert fald mente regeringen i en ny forestilling af 9 . juni til kongen, at de betænkeligheder, der havde kunnet være forbundet med at sammenkalde Rigsrådet, ikke længere var til stede. Man indstillede derfor, at Rigsrådet sammenkaldtes den 20. juni.

Kongen var åbenbart ikke enig. Den kongelige resolution den 10. juni lyder: »Indstillingen [af 9. juni] bifaldes, dog således at for så vidt konferencerne ikke måtte være sluttede til den 20. d.m., vil Rigsrådets sammentræden blive at udsætte indtil en nærmere bestemmende dag. ${ }^{89}$

Regeringen indså hurtigt, at man ikke kunne løbe an på, at Londonkonferencerne ville være slut den 20. juni. Kun tre dage efter, den 13. juni, forelå der nemlig atter en forestilling. D.G. Monrad indstillede under henvisning til, at våbenhvilen udløb den 25. juni, at Rigsrådet 
* J J eg lover og sværger ubrødeligen at holde Grundloven for Kongeriget Danmarks og Hertugdømmet Slesvigs Fællesanliggender, saasandt hjælpe mig Gud og hans hellige Ord.

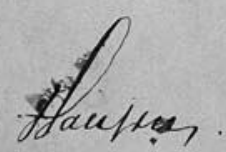

Ed aflagt af biskop for Als-Ærø Bispedømme Jørgen Hansen (1802-1889), da han indtog sin plads $i$ Rigsrådets landsting. Folketingets Bibliotek. Rigsrådets arkiv. Journalsager nr. 888. Foto: Jonas Vest.

indkaldtes denne dag. Dette approberedes af kongen, og det åbne brev om indkaldelsen blev udfærdiget. ${ }^{90}$

\section{Det nyvalgte rigsråd}

Den 25. juni oversendte Finansministeriet fortegnelserne over medlemmerne af de to ting til aldersformændene i henholdsvis Rigsrådets folketing og landsting. ${ }^{91}$ Hver fortegnelse var ledsaget af en fremsendelsesskrivelse med særlige bemærkninger. Vedrørende medlemmerne til Rigsrådets folketing anførte D.G. Monrad, at okkupationen var skyld i, at der i kongeriget ikke til den berammede tid var valgt et medlem i Vejles 2. kreds, men at Finansministeriet havde foretaget det fornødne for, hvis det blev muligt, at kunne foretage valg i denne kreds. For Slesvigs vedkommende nævnte han ligeledes okkupationen som årsag til, at der kun havde været afholdt valg $i$ tre af kredsene. Han anførte bemærkelsesværdigt nok ikke yderligere noget om eventuelle forestående valg. Det kunne tyde på, at han ikke anså det for realistisk.

Af bemærkningerne angående Rigsrådets landsting skal her kun nævnes, at der i henhold til Novemberforfatningen var udnævnt tre 
nye kongevalgte slesvigske medlemmer til landstinget til supplering af de fra det foregående rigsråd stammende tre kongevalgte slesvigske medlemmer, hvoraf et dog var afgået ved døden. ${ }^{92}$ Af kongevalgte medlemmer kunne der i alt være 18, hvoraf de seks skulle være bosiddende i Slesvig på tidspunktet for deres valg. ${ }^{93}$

På sikker afstand af krigen og krigsforholdene i Jylland samledes Rigsrådet i København. Alligevel var krigen dog nærværende, idet man helt konkret blev mindet om den gennem afbud til Rigsrådets møder. Den 29. juni meddelte biskop Jørgen Hansen, Als, formanden for Rigsrådets landsting, at han "på grund af krigsbegivenhederne" måtte rejse bort og ikke kunne give møde foreløbig. ${ }^{94}$ Det er der ikke noget at sige til, for om natten var fjenden gået over Alssund og havde erobret Als. Krigen var nu blevet genoptaget efter udløbet af våbenhvilen den 26. juni. Senere begrundede landstingsmand grev Frijs til Frijsenborg, hvorfor han ikke havde kunnet og ikke kunne give møde. Fjendens indkvartering og rekvisitioner krævede hans tilstedeværelse derhjemme. ${ }^{95}$ Endelig skal det erindres, at kaptajnløjtnant O.C. Hammer, som tidligere omtalt, på grund af sin militære kommando ikke havde kunnet give møde.

\section{Krigen og valget}

Valget til Rigsrådet, der som udgangspunkt var blevet fremskyndet, fordi Rigsrådet ellers tidligst ville kunne give møde efter midten af april, gik på grund af krigen hen og blev en langstrakt affære under akkompagnement af krigens larm og uro. På trods af at krigen greb ind i valgenes konkrete forberedelse, gennemførelse og resultat, så blev valget gennemført så vidt overhovedet muligt. Der blev ikke grebet til kortslutninger i form af blot at opgive valgene. Det var i de bevægede dage efter tilbagetrækningen fra Dannevirke ikke overalt en selvfølge, at valgene skulle gennemføres. Det vidner en forespørgsel om fra den nys konstituerede amtmand over Als og Ærø. Den 9. februar udbad han sig telegrafisk en bemyndigelse til at standse forberedelserne til Rigsrådsvalgene i Sønderborg og Nordborg Amter, da forholdene gjorde det umuligt at fremme sagen, »der nu også turde være uden praktisk interesse «. ${ }^{96}$ Svaret var afvisende. I Finansministeriets journal er svaret kort og godt anført med »nej «. ${ }^{97}$

Nok lod Novemberforfatningen - set ud fra en liberal og demokratisk målestok - meget tilbage at ønske med sin begrænsede valgret til 
Rigsrådets landsting i forhold til valgene til Rigsdagens landsting i henhold til Junigrundloven, men valgene blev så vidt overhovedet muligt gennemført endog med brug af kreative løsninger for at få landstingsvalgene gennemført i de slesvigske valgkredse. At man evnede at gennemføre valgene i det omfang, som man faktisk gjorde, må kunne betragtes som en lille civil sejr midt i nederlaget. Ikke nok med at man afholdt valgene til Rigsrådets folketing og landsting, men man evnede også at gennemføre valg til Rigsdagens folketing den 7 . juni. ${ }^{98}$ Dog med den forskel, at der var våbenhvile på det tidspunkt.

Krigen i 1864 som nationalt traume på grund af det militære nederlag og den senere forfatningskamp kan nemt komme til at skygge for valgene og anstrengelserne om trods alt at finde sig til rette med den nye styreform kun godt 15 år efter enevældens ophør i Danmark.

\section{FORKORTELSER}

FB: Folketingets Bibliotek.

FM: Finansministeriet.

MHS: Ministeriet for Hertugdømmet Slesvig.

RA: Rigsarkivet.

\section{KILDER OG LITTERATUR}

\section{Utrykte kilder:}

Folketingets Bibliotek, Christiansborg, Rigsrådet. C. Journalsager. 9.1. Overordentlig samling 1864.

Rigsarkivet, Budgetdepartementet, Finansministeriets Sekretariat: Rigsrådssager (1854-1865) 759: 1864-1865.

Rigsarkivet, Finansmin., Finansdepartementet, Sekretariats- og budgetkontor: Forestillinger (1848-1975) 30: 1864.

Rigsarkivet, Finansmin., Finansdepartementet, Sekretariats- og budgetkontor: Forestillinger (1848-1975) 31: 1864 m.m.

Rigsarkivet, Finansmin., Finansdepartementet, Sekretariats- og budgetkontor: Journal (1849-31.03.1940) 258: 1864 m.m.

Rigsarkivet, Kabinetssekretariatet: Ajournalsager (1853-1905) 740: 18641865.
Rigsarkivet, Kabinetssekretariatet: Kabinetsjournal A (1853-1946) 686: 1864.

Rigsarkivet, Kabinetssekretariatet: Konceptbøger til danske og tyske reskripter og resolutioner (1843-1905) 434: 1863-1865.

Rigsarkivet, Ministeriet for Hertugdømmet Slesvig, Sekretariatet: Sager angående Rigsrådet og valg til dette (1854-1864) 1 .

Rigsarkivet, Ministeriet for Hertugdømmet Slesvig 2. Departement, 1. Kontor: Journalregister (1852-1864) 6: 1862-1864.

Rigsarkivet, Ministeriet for Hertugdømmet Slesvig 2. Departement, 1. Kontor: Journaler (1852-1864) 14: 1864.

Rigsarkivet, Ministeriet for Hertugdømmet Slesvig 2. Departement, 1. Kontor: Kopibog (1864-1864) 1: m.m. 
Rigsarkivet, Ministeriet for Hertugdømmet Slesvig, Sekretariatet: Indberetninger om den politiske tilstand og stemning (1864-1864) 1.

Rigsarkivet, Indenrigsministeriet, 3. Kontor: Rigsdagsjournalsager (18481967) 126: 1848-1866. J.nr. 686-704 m.m.

\section{Trykte kilder:}

Chronologisk Samling af de i Aaret 18511864 emanerede Forordninger og Rescripter etc. for Hertugdømmet Slesvig. Bd. I-VIII. Slesvig 1855-1865 [Dækker til og med januar 1864].

Danske Forfatningslove og Forfatningsudkast. Udgivet med indledninger af Himmelstrup, Jens og Jens Møller, København 1932.

Departementstidende 1848-1870. Syttende årgang. 1864. Udg. J. Liebe, København.

Hof-og Statskalenderen 1864.

Rigsdagstidende, Sextende Samling 1864.

Rigsraadstidende, Overordentlig Samling 1864.

Rigsraadstidende, 2den overordentlige Samling 1864.

Statsraadets Forhandlinger 1863-1864, IX, København 1970 ved Harald Jørgensen.

Statsraadets Forhandlinger om Danmarks Udenrigspolitik 1863-1879. Uddrag af Statsraadsprotokollerne ved Aage Friis, 1936 [Forsynet med noter].

\section{Litteratur:}

Bjørn, Claus: »1814-1864«, Dansk udenrigspolitisk historie, bd. 3, 1814-1914, København 2003.

Det kongelige Bibliotek, København, og Det Slesvig-Holstenske Landsbibliotek, Kiel (udg.): Bibliografi og ikonografi 1864, Neumünster 1970.

Dansk Biografisk Leksikon (3. udg.), www.denstoredanske.dk/Dansk_ Biografisk_Leksikon. Onlineudgave pr. 1. marts 2014.

Generalstaben (udg.): Dansk-tydske krig, Den, II og III, København 1891 og 1892.

Hammer, Otto Chr.: Vesterhavsøernes Forsvar i Aaret 1864, København 1865. von Jessen, Franz: Mit Livs Egne, Hændelser, Mennesker. Første Del, 18701902, København 1943.

Lauesgaard, A.: Fortegnelse over Rigsdagsvalgene, Rigsdagssamlingerne, Ministrene, Rigsdagens Formænd, Medlemmerne af den grundlovgivende Rigsforsamling og af Rigsdagen 1848-1916 samt [...], København 1916.

Møller, Erik: Helstatens Fald I \& II, København 1958 (genoptrykt 1974).

Neergaard, N. Under Junigrundloven I \& II, København 1892 og 1916 (genoptrykt 1973).

Nielsen, Johs.: 1864. Da Europa gik af lave, Odense 1987.

Noack, Johan Peter: Da Danmark blev Danmark, København 2014.

Nørr, Erik og Jesper Thomassen (red.): Slesvig, Preussen, Danmark. Kilder til sønderjysk forvaltningshistorie, København 2004.

Nørr, Erik m.fl.: Theodor Gliemanns amtskort over hertugdømmet Slesvig, Aabenraa 2008.

Pørksen, Claus: »Kampen om Vesterhavsøerne i 1864«, Sønderjyske Arbøger 2013, s. 31-62.

von Rosen, Wilhelm (red.): Rigsarkivet og hjxlpemidlerne til dets benyttelse II, 1848-1890 bd. 1, Odense 1991.

Schlaber, Gerret Liebing: Hertugdømmet Slesvigs forvaltning. Administrative strukturer og retspleje mellem Ejderen og Kongeåen ca. 1460-1864. Flensborg 2007a.

Schlaber, Gerret Liebing: Administrative tilhørsforhold mellem Ejderen og Kongeåen indtil 2007, Flensborg 2007b.

Schultz Hansen, Hans: "Nationalitetskamp og modernisering 1815-1918«, Hans Schultz Hansen m.fl. (red.): Sønderjyllands Historie - Efter 1815, Aabenraa 2009.

Skovmand, Roar: Danmarks Historie, bind 11, København 1964.

Stenz, Chr.: "Sønderjyder under junigrundloven«, Sønderjyske Årbøger 1980, s. 184-232.

Vammen, Hans: Den tomme stat. Angst og ansvar i dansk politik 1848-1864, København 2011. 


\section{NOTER}

1. RA. Finansministeriet. Forestillinger 1848-1972, 1864, forestilling nr. 34 med Åbent Brev af 31.1.1864.

2. Neergaard II 1916, s. 1001, og Møller II 1958, s. 37.

3. Denne iagttagelse bygger på brug af følgende bibliografier og hjælpemidler: Bibliografi og ikonografi, Dansk Historisk Arsbibliografi 1967, 1968, 1969, Dansk Historisk Bibliografi 1970-1973. 1974-1976, Dansk Historisk Bibliografi online via www.kb.dk, Register til Sønderjyske Årbøger 1889-1988, 1989, Sønderjyske Arbøger 1989-2013, Historisk Tidsskrift e-udgave via www. tidsskrift.dk, Historisk Tidsskrift 20082013, suppleret med søgninger i wwww.rex.kb.dk og www.bibliotek.dk og Schleswig-Holsteinische Bibliographie via www.shlb.de/abacus-cgi/shbib. pl.

4. Eksempelvis Dansk Biografisk Leksikon om Sofus Høgsbro, og Peter Lampe: »Peter Jørgensen, degnen på Als, som kom i Rigsrådet«, Sønderjysk Månedsskrift 1967, nr. 5.

5. Det synes ikke oplagt, at valg til Rigsrådet hørte under Finansministeriet, men da Ministeriet for Monarkiets Fælles Indre Anliggender blev nedlagt i 1858 efter en kort levetid på knap tre år, blev dets ressort henlagt under Finansministeriet, der således kom til at fungere som fælles indenrigsministerium. Von Rosen 1991, s. 226.

6. En del af pakkens indhold skiller sig ud ved 1) ikke at være behandlet i Ministeriet for Hertugdømmet Slesvig, og ved 2) at vedrøre Vesterhavsøerne. Der er formentlig tale om arkivalier, der stammer fra Den Interimistiske Overøvrighed for Vesterhavsøerne. Den 27.7.1864 meddelte den konstituerede amtmand A. Villemoes MHS, at han nu var blevet fjernet af fjenden, og at han indsendte de akter, som var opstået under hans virke som Interimistisk overøvrighed for Vesterhavsøerne, til ministeriet. Se RA. Ministeriet for Hertugdømmet Slesvig, 2. Departement, 1. Kon- tor: Journaler (1852-1864). 1864, J.nr. 582. Der findes således flere end "de få efterladte akter«, som nævnt hos Schlaber 2007a.

7. Af 326 vælgere var 270 bønder. RA. Budgetdepartementet, Finansministeriets Sekretariat, Rigsrådssager, 1864-1865. Jørgen Hansen 31.3.1864 til Finansministeriet, FM j.nr. 1107/ 1864.

8. RA. Budgetdepartementet, Finansministeriets Sekretariat, Rigsrådssager, 1864-1865. Jørgen Hansen 31.3. 1864 til Finansministeriet, FM j.nr. $1107 / 1864$.

9. RA. Budgetdepartementet, Finansministeriets Sekretariat, Rigsrådssager, 1864-1865. Jørgen Hansen 19.4. 1864 til Finansministeriet, FM j.nr. 1356/1864.

10. Vedr. Aftalerne af 1851-52, se Møller I 1958, s. $62 \mathrm{ff}$.

11. Selve Januarkundgørelsen, se Danske Forfatningslove 1932, s. 74 ff. Vammen 2011, s. 73 og 84 ff., giver en udmærket kortfattet fremstilling. Se også Neergaard I 1892, s. 569 ff.

12. I Januarkundgørelsen gav kongen tilsagn om udarbejdelse af en forfatning for monarkiets frlles anliggender, dvs. en helstatsforfatning. Desuden gav han tilsagn om, at hver del af monarkiet skulle have sin egen forfatning. Samtidig blev en række sagsområder straks udskilt til at være helstatsanliggender og dermed unddraget Rigsdagens kontrol.

13. Dette skete som optakt til Forfatningsloven af 2.10.1855 for det Danske Monarkis Fællesanliggender. Forfatningsloven blev dog ophævet 6.11.1858 for Holstens og Lauenborgs vedkommende.

14. Betegnelsen »Kongeåen « anvendes i artiklen som synonym for grænsen mellem kongeriget Danmark og hertugdømmet Slesvig.

15. Vedr. forfatningshistorien i løbet af 1850 'erne henvises til gængse opslagsværker, senest Sønderjyllands Historie bd. 2. Den dybdeborende gennemgang skal søges i klassiker- 
ne Erik Møller: Helstatens Fald I \& II og Neergaard: Under Junigrundloven I \& II. Som sammenfatning og oversigt med profilering af begivenhederne foreligger Johan Peter Noack: Da Danmark blev Danmark. Se f.eks. definitionen på statskup s. 139 i forbindelse med omtalen af januarkundgørelsen. Endelig et anderledes, men særdeles oplysende værk, Hans Vammen: Den tomme stat.

Det skal i denne sammenhæng bemærkes, at Rigsrådet blev »opfundet«i 1854 og ændret i 1855 . Holsten og Lauenborg trådte dog ud af Rigsrădet $\mathrm{i}$ 1858. Med Novemberforfatningen omfattede Rigsrådet kun Danmark og Slesvig.

16. Optælling foretaget på basis af Rigsraadstidende, Overordentlig Samling 1864, og Rigsdagstidende, Sextende Samling 1864.

17. Fordelt på 101 i folketinget, 52 i landstinget og 12 kongevalgte i landstinget.

18. Forordningen blev givet i medfør af tilsagn i Januarkundgørelsen. I nærværende sammenhæng skal nævnes, at forordningen fastslog, at hertugdømmet Slesvig havde sin egen lovgivning og forvaltning, og at hertugdømmets folkelige repræsentation, Provinsialstænderforsamlingen, havde besluttende myndighed inden for sin virkekreds. Denne myndighed rakte dog kun til samtykke til forandring i lovgivningen (§ 12), endog med visse indskrænkninger (§ 13). Der var heller ikke lovgivningsmæssig initiativret (§16). Ministeransvar over for repræsentationen var der kun tale om i tilfælde af, at ministeren uberettiget havde gjort brug af provisorisk lovgivning (§15). Domstolene måtte ikke bedømme den udøvende magt (§9). Tilligemed var ytringsfriheden vedr. offentlige anliggender begrænset (§8). Det var en konservativ forfatning og et barn af enevældens tankegods. En noget lignende forordning for Holstens vedkommende blev givet knap fire måneder senere. Se i øvrigt Neergaard II 1916, s. 64ff.

19. Foreløbig Lov om nogle Foran- dringer i de ved Lov af 4.12.1863 angående Valgene til Rigsraadet foreskrevne Tidsbestemmelser, 31.1. 1864.

20. RA. Finansministeriet. Forestillinger 1848-1972, 1864, forestilling nr. 32, 31.1.1864 med kgl. res. af samme dato.

21. RA. Finansministeriet. Forestillinger 1848-1972, 1864, forestilling nr. 34, 31.1.1864 med $\mathrm{kgl}$. res. af samme dato.

22. Møller II, 1958, s. 36ff.

23. Statsrådets forhandlinger 19.1.1864, i Statsraadets Forhandlinger 18631864, 1970.

24. Neergaard II 1916, s. 1001.

25. RA. Kabinetssekretariatet journalsager 1853-1905. 1864-65. A nr. 52. Udenrigsministeriets forestilling af 22.1.1864. Jf. Neergaard II 1916, s. 1011.

26. RA. Ministeriet for Hertugdømmet Slesvig, Sekretariatet. Sager angående Rigsrådet og valg til dette (18541864). Finansministeriet til Ministeriet for Hertugdømmet Slesvig 16.1.1864. MHS j.nr. 73 og 74. FM j.nr. 162/1864 og 161/1864.

27. RA. Finansministeriet. Sekretariatet, Forestillinger 1848-1972. Forestilling nr. 24 af 26.1.1864 med kgl. res. af samme dato, FM j.nr. 269. Forestilling nr. 36 af 3.2.1864 med kgl. res. af samme dato, FM j.nr. 346b/1864.

28. Her valgtes i 4 . slesvigske bydistrikt borgmester H. Finsen, Sønderborg, iflg. indberetning af 18.6.1864 om valg afholdt 5 . marts s. å. fra valgbestyrer Grønlund i Nordborg, FM. j.nr. 2030/1864, i 6. slesvigske landdistrikt lærer og degn P. Jørgensen, Hørup, iflg. indberetning af 6.3.1864 fra herredsfoged Arnesen i Augustenborg, FM j.nr. 729/1864, og i 1. slesvigske blandede distrikt assessor B.N.E. Steenstrup, Ærøskøbing, iflg. indberetning fra landfoged Carstens i Ærøskøbing af 6.3.1864, FM j.nr. 748. RA. Budgetdepartementet, Finansministeriets Sekretariat, Rigsrådssager, 1864-1865.

29. RA. Finansministeriet. Sekretariatet, Forestillinger 1848-1972. Forestilling nr. 42 med kgl. res. af 12.2.1864. 
Hvervet overgik herefter til herredsfoged A. Grønlund i Nordborg.

30. RA. Budgetdepartementet, Finansministeriets Sekretariat, Rigsrådssager, 1864-1865. Indberetning af 20.6.1864 fra amtmand Dahl i Vejle, FM j.nr. 2077/1864.

31. RA. Budgetdepartementet, Finansministeriets Sekretariat, Rigsrådssager, 1864-1865. Indberetning af 5.3.1864 fra valgbestyrelsesformanden, FM j.nr. 737/1864. Se også Stenz 1980, s. 194 og s. 224.

32. RA. Finansministeriet. Sekretariatet, Forestillinger 1848-1972. Forestilling nr. 66 af 7.3 .1864 med kgl. res. af 8.3.1864.

33. RA. Finansministeriet. Sekretariatet, Forestillinger 1848-1972. Forestilling nr. 82 af 19.3 .1864 med kgl. res. af 21.3.1864.

34. Se Lov af 4.12.1863 angaaende Valgene til Rigsraadet, § 17, der henviser til at anvende reglerne som anført i Foreløbig Lov af 2.10.1855 angaaende Valgene til Rigsraadet, §§ 18-28.

35. RA. Budgetdepartementet, Finansministeriets Sekretariat, Rigsrådssager, 1864-1865, FM j.nr. 764 og 788/ 1864.

36. RA. Finansministeriet. Sekretariatet, Forestillinger 1848-1972. Forestilling nr. 81 af 21.3.1864 med kgl. res. af samme dato. Byfoged og byskriver i Skanderborg og herredsfoged i Hjelmslev-Gjern herreder A.F. Bülow beskikkes.

37. RA. Finansministeriet. Sekretariatet, Forestillinger 1848-1972. Forestilling nr. 88 af 22.3.1864 med kgl. res. af 1.4.1864. Birkedommer og skriver i Frijsenborg-Faurskov birk C.O. Malling beskikkes.

38. RA. Budgetdepartementet, Finansministeriets Sekretariat, Rigsrådssager, 1864-1865. Indberetning af 18.4. 1864 fra birkedommer i FrijsenborgFaurskov birk C.O. Malling, FM j.nr. 1336/1864. 428 stk. stemmesedler udsendt.

39. RA. Budgetdepartementet, Finansministeriets Sekretariat, Rigsrådssager, 1864-1865, FM j.nr. 837/1864.

40. RA. Budgetdepartementet, Finansministeriets Sekretariat, Rigsrådssa- ger, 1864-1865. Indberetning af 14.5. 1864 fra birkedommer i FrijsenborgFaurskov birk C.O. Malling, FM j.nr. 1629/1864.

41. RA. Budgetdepartementet, Finansministeriets Sekretariat, Rigsrådssager, 1864-1865. Indberetning af 4.6. 1864 fra birkedommer i FrijsenborgFaurskov birk C.O. Malling. FM j.nr. 1891/1864. 481 stk. stemmesedler udsendt.

42. Der er i nærværende arbejde ikke foretaget nærmere undersøgelser vedrørende de til Ribe Amt og dermed 11. landstingsvalgkreds hørende kongerigske enklaver, hvad landstingsvalget angår.

43. RA. Budgetdepartementet, Finansministeriets Sekretariat, Rigsrådssager, 1864-1865. Indberetning af 30.3. 1864 fra amtmanden i Ringkøbing. FM j.nr. 1123/1864. Amtmanden mente ikke, man i henhold til valgloven kunne undgå at bekendtgøre stedet for valghandlingen, da loven foreskrev offentlig valghandling.

44. RA. Budgetdepartementet, Finansministeriets Sekretariat, Rigsrådssager, 1864-1865. Indberetning 6.4. 1864, FM j.nr 1175/1864.

45. RA. Budgetdepartementet, Finansministeriets Sekretariat, Rigsrådssager, 1864-1865. Skrivelse fra amtmanden til Finansministeriet af 8.4.1864, FM j.nr. 1199/1864.

46. RA. Budgetdepartementet, Finansministeriets Sekretariat, Rigsrådssager, 1864-1865, FM j.nr. 1283/1864.

47. I Rigsrådets landstings 8 . kreds afholdtes valget den 29.3.1864 i Thisted. RA. Budgetdepartementet, Finansministeriets Sekretariat, Rigsrådssager, 1864-1865, FM j.nr. 1122/ 1864.

48. RA. Finansministeriet. Sekretariatet, Forestillinger 1848-1972. 1864. Forestilling nr. 53. Foreløbig Lov af 24.2. 1864, hvorved Finansministeriet bemyndiges til at foretage Forandringer i de for Forberedelserne til de forestående Rigsrådsvalg foreskrevne Frister samt til at forandre de foreskrevne Valgdage.

49. Krigens geografi er her skildret på baggrund af Den Dansk-Tydske Krig. 
50. Våbenhvilen gik fra tysk side ud på stillingsmæssig status quo, tilladelse af handelens, kommunikationens og administrationens regelmæssige gang i den besatte del af Jylland og endelig ingen opkrævning af krigsskat (kontribution) i de besatte områder. Den danske modydelse var ophævelse af blokaden af de tyske havne. Nielsen 1987, s. $302 \mathrm{ff}$.

51. Mod vest lå 13. landstingsvalgkreds: Haderslev, Tønder og Løgumkloster Amter. Mod øst lå 14. landstingsvalgkreds: Aabenraa, Sønderborg, Nordborg og Flensborg Amter samt staden Flensborg og Kappel Herred. Mod syd lå 15. landstingsvalgkreds: Bredsted og Husum Amter med Eidersted, Gottorp, Hytten og Femern Amter samt Egernførde Herred.

52. RA. Ministeriet for Hertugdømmet Slesvig, Sekretariatet. Sager angående Rigsrådet og valg til dette (18541864). Udkast til skrivelsen af 3.3. 1864 fra MHS til Finansministeriet, MHS j.nr. 267/1864. Heri beskrives detaljeret, hvilke valgkredse Vesterhavsøerne lå $\mathrm{i}$.

53. RA. Ministeriet for Hertugdømmet Slesvig, Sekretariatet. Sager angående Rigsrådet og valg til dette (18541864). Finansminister D.G. Monrad til MHS 26.2.1864. MHS j.nr. 267.

54. Lov angaaende Valgene til Rigsraadet, 4.12.1863, §§ 15 og 17. Valglisterne skulle for landstingets vedkommende i Slesvig udarbejdes af underdommerne iflg. $\mathrm{kgl}$. res. af 3.2.1864, forestilling nr. 36, FM j.nr. $346 \mathrm{~b} / 1864$.

55. Broder Knudsen.

56. RA. Budgetdepartementet, Finansministeriets Sekretariat, Rigsrådssager, 1864-1865. Indberetning af 10.2. 1864 fra herredsfoged Arnesen, Augustenborg Herred: Mens amtmand Heltzen selv forblev i Aabenraa, konstituerede han den 6. februar P.K.M. Arnesen som amtmand over Als, Ærø og den ubesatte del af Sundeved, FM j.nr. 475/1864.

57. Kommissorium af 7.3.1864, RA, Ministeriet for Hertugdømmet Slesvig. 2. dep. 1. kontor. Kopibog, j.nr. 338 II A.
58. RA. Ministeriet for Hertugdømmet Slesvig, Sekretariatet. Sager angående Rigsrådet, og valg til dette (18541864). Skr. af 10.3.1864 fra Ministeriet for Hertugdømmet Slesvig til provst Otzen. J. nr. 334.

59. Foreløbig Lov af 4.12.1863 angaaende Valgene til Rigsraadet, $\S 16$.

60. RA. Finansministeriet. Forestillinger 1848-1972. Forestilling nr. 62 af 4.3. 1864 med kgl. res. af 5.3.1864.

61. Vedrørende amternes udstrækning, se Nørr 2008, og Schlaber 2007b.

62. RA. Ministeriet for Hertugdømmet Slesvig, Sekretariatet. Sager angående Rigsrådet og valg til dette (18541864). Skr. af 2.2.1864 til Finansministeriet. Jf. Finansmin., Finansdepartementet, Sekretariats- og budgetkontor: Journal (1849-31.03.1940). FM j.nr. 346a/1864.

63. RA. Ministeriet for Hertugdømmet Slesvig, Sekretariatet. Indberetning om den politiske tilstand og strømning. Afhøring af amtmand Broder Knudsen den 8.4.1864.

64. FB. Rigsrådets arkiv. C. Journalsager, 9. 1. overordentlige samling 1864, j. nr. 827. Finansministeriet til aldersformanden for Rigsrådets landsting.

65. RA. Budgetdepartementet, Finansministeriets Sekretariat, Rigsrådssager, 1864-1865. Indberetning af 2.4. 1864 til Finansministeriet fra Den Interimistiske Overøvrighed for Vesterhavsøerne, FM j.nr. 1170.

66. Det samme var Rømøs nordland, der hørte til Haderslev Amt og dermed også til 13. valgkreds.

67. Rigsraadstidende. Forhandlinger paa Landsthinget. Overordentlig Samling 1864. Sp. 12. Biskop Hansen redegjorde her for valgets forløb.

68. RA. Budgetdepartementet, Finansministeriets Sekretariat, Rigsrådssager, 1864-1865. Indberetning af 19.3.1864 fra valgbestyrelsen, FM j.nr. 946/1864.

69. RA. Budgetdepartementet, Finansministeriets Sekretariat, Rigsrådssager, 1864-1865. Jørgen Hansen 19.4.1864 til Finansministeriet, FM j.nr. 1356.

70. RA. Budgetdepartementet, Finans- 
ministeriets Sekretariat, Rigsrådssager, 1864-1865. FM j.nr. 1176, 1044, $1056,1121,1891 / 1864$. Kun i 5 ud af 11 indberetninger var det tilgrundliggende antal stemmesedler anført. I indberetningen fra Bornholms Amt var antal af udsendte stemmesedler ikke angivet. Det nøjagtige behov, nemlig 88, er dog opgjort i forbindelse med returnering af overskydende stemmesedler. Bornholms Amt til Finansministeriet 22.3.1864, FM j.nr. 998.

71. RA. Ministeriet for Hertugdømmet Slesvig, Sekretariatet. Sager angående Rigsrådet og valg til dette (18541864). 7.3.1864. Finansministeriet til Den Interimistiske Overøvrighed for Vesterhavsøerne.

72. RA. Budgetdepartementet, Finansministeriets Sekretariat, Rigsrådssager, 1864-1865. 11.4.1864. Villemoes til Finansministeriet, FM j.nr. 1284/ 1864.

73. RA. Ministeriet for Hertugdømmet Slesvig, Sekretariatet. Sager angående Rigsrådet og valg til dette (18541864). Protokol for valgbestyrelsen i 13. landstingsvalgkreds, 24.5.1864.

74. RA. Ministeriet for Hertugdømmet Slesvig, Sekretariatet. Sager angående Rigsrådet og valg til dette (18541864). Protokol for valgbestyrelsen $i$ 13. landstingsvalgkreds, 24.5.1864.

75. RA. Ministeriet for Hertugdømmet Slesvig, Sekretariatet. Sager angående Rigsrådet og valg til dette (18541864). 5.5.1864 [må være skrivefejl for 5.6.1864]. Christian Juhl til herredsfoged Villemoes, der er fmd. for valgbestyrelsen: »På grund af de for tiden herskende forhold, [ser han sig] foreløbig ikke i stand til at modtage valget, ...«.

76. RA. Ministeriet for Hertugdømmet Slesvig, Sekretariatet. Sager angående Rigsrådet og valg til dette (18541864). 1.6.1864. W. Johansen til valgbestyrelsen for valgene til Rigsrådets landsting for 13 . valgkreds. Der gives ikke nogen særskilt begrundelse.

77. RA. Ministeriet for Hertugdømmet Slesvig, Sekretariatet. Sager angående Rigsrådet og valg til dette (1854-
1864). 23.6.1864. Finansministeriet til Den Interimistiske Overøvrighed for Vesterhavsøerne.

78. RA. Ministeriet for Hertugdømmet Slesvig, Sekretariatet. Sager angående Rigsrådet og valg til dette (18541864). Valgbestyrelsens forhandling, Vyk den 6.7.1864.

79. RA. Budgetdepartementet, Finansministeriets Sekretariat, Rigsrådssager, 1864-1865. Villemoes til Finansministeriet 7.7.1864. FM j.nr. 2407/ 1864.

80. Hammer 1865, s. 96.

81. RA. Ministeriet for Hertugdømmet Slesvig. Sekretariatet. Indberetning om den politiske tilstand og stemning. 1864. Afskrift af toldkontrollør i Keitum, Sild, Masorskys indberetning til Generalpostdirektoratet.

82. FB. Rigsrådets arkiv. Journalsager. 1. overordentlige samling 1864. Arkivnr. 857.

83. FB. Rigsrådets arkiv. Journalsager. 1. overordentlige samling 1864. Arkivnr. 858. Til præsidenten for Rigsrådets landsting, dateret dampskibet Liimfjorden den 8.7.1864.

84. Rigsraadstidende. Overordentlig samling 1864. 1. møde den 25.6.1864, sp. 5-38.44, og møde den 25.8.1864, sp. 669-682.

85. Neergaard II 1916, s. 1223 og s. 1297.

86. I henhold til 1863-grundlovens $§ 59$.

87. I henhold til 1863-grundlovens $§ 58$.

88. RA. Finansministeriet. Sekretariatet, Forestillinger 1848-1972. 1864. Uden nr. 2.6.1864. FM j.nr. 1946/1864.

89. RA. Finansministeriet. Sekretariatet, Forestillinger 1848-1972. 1864. Nr. 164. FM j.nr. 1947/1864.

90. RA. Finansministeriet. Sekretariatet, Forestillinger 1848-1972. 1864. Nr. 165. FM j.nr. 1949/1864.

91. FB. Rigsrådets arkiv. C. Journalsager, 9. 1. overordentlige samling 1864, j. nr. 827. Finansministeriet til aldersformanden for Rigsrådets landsting og Finansministeriet til aldersformanden for Rigsrådets folketing.

92. Valgperioden var 12 år og af Novemberforfatningen $\S 26$ fremgår, at hidtidige kongevalgte medlemmer af Rigsrådet forbliver, indtil de 12 år er udløbet for hver enkelt. 
93. De fem slesvigske var: Præsident i den $\mathrm{kgl}$. appellationsret for hertugdømmet Slesvig C.L.E. v. Stemann, skibsreder og rådmand i Sønderborg C. Jensen og skibsreder P.W. Brandt $i$ Ærøskøbing, samt de hidtidige købmand P. Schmidt og landkommissær M. Hagemann.

94. FB. Rigsrådets arkiv. C. Journalsager, 9. 1. overordentlige samling 1864, j. nr. 865.

95. FB. Rigsrådets arkiv. C. Journalsager, 9. 1. overordentlige samling $1864, \mathrm{j}$. nr. 855. Skr. af 13.7.1864. Sst. j.nr. 845 . Skr. af 1.7.1864.

96. RA. Budgetdepartementet, Finansministeriets Sekretariat, Rigsrådssa- ger, 1864-1865. Telegram fra konstitueret amtmand Arnesen til Finansministeriet, FM j.nr. 430/1864.

97. RA. Finansministeriets Finansdepartementets sekretariats- og budgetkontor. Journal 1864. Nr. 430.

98. RA. Indenrigsministeriet, 3. Kontor: Rigsdagsjournalsager 1864, j.nr. 735. Valget var oprindeligt udskrevet den 16.4.1864 til afholdelse ved valgperiodens udløb den 14.6.1864. Indenrigsministeren fandt det dog ønskeligt, at det i stedet afholdtes den 7.6.1864 inden våbenhvilens udløb. Kongelig resolution herom den 20.5.1864.

\section{Zusammenfassung}

Der Krieg zwischen Dänemark und den deutschen Großmächten 1864 beeinträchtigte die Wahlen zum Reichsrat in diesem Jahr. Die Gesetzesänderungen, die kurz vor Kriegseinbruch verabschiedet waren, um die Wahlen durch Verkürzung der Zeitfristen zu beschleunigen, wurden von den Begebenheiten überholt. Jetzt wurde es in der Vorbereitungsphase möglich rein verwaltungsmäßig die Zeitfristen zu verlängern und Wahlstellen zu ändern.

Bei der Durchführung können die Kriegsbegebenheiten und die Ausbreitung der Besetzung in den Änderungen verfolgt werden, die bei Durchführung der Wahlen stattfinden, wie Änderungen in der Berufung der Wahlvorsitzenden, Änderungen in den Stellen für die Wahlhandlungen und Änderung von Zeitpunkten. Die Durchführung wurde auch durch eine unsichere Kommunikation als Folge der Kriegsereignisse und der Besatzung gekennzeichnet.

Das Ergebnis war, dass in großen Teilen Schleswigs keine Wahlen zum Volksting des Reichsrats durchgeführt wurden, wie es in Dänemark bei allen anderen Wahlen - mit einer einzelnen Ausnahme zum Volksting des Reichsrats der Fall war. Zum Landesting wurden in Dänemark sämtliche Wahlen durchgeführt. Die Wahlen in den schleswigschen Landestingswahlkreisen wurden teilweise durchgeführt, nach bemerkenswerten Initiativen der Regierung zur Durchführbarkeit in den unbesetzten Teilen der Wahlkreise.

Trotz aller Schwierigkeiten wurden die Wahlen zum Reichsrat laut 
Novemberverfassung durchgeführt. Der Reichsrat konnte zusammentreten, wenn es nötig war, nun nicht zur Verhinderung des Kriegsausbruchs, sondern um zu einer Friedensabmachung oder Weiterführung des Krieges Stellung zu nehmen, und weil im Namen der Regierung nicht weiterhin - in gewissem Umfang erlaubte - vorläufige Gesetze verabschiedet werden konnten. 